\title{
Towards a Qualitative Model of Religious Worship Experiences: Perceived Encounters with the Divine in the Ritual Context of Musical Devotion Practices
}

\author{
Yoshija Walter ${ }^{1 \mathrm{a}, \mathrm{b}, \mathrm{c}}$ \\ ${ }^{a}$ Laboratory for Cognitive Neurosciences, University of Fribourg, Switzerland \\ ${ }^{b}$ University Hospital of Psychiatry UPD, University of Bern, Switzerland \\ ${ }^{c}$ Institute for Management and Digitalization, Kalaidos University of Applied Sciences Zurich, \\ Switzerland
}

\begin{abstract}
The current qualitative study investigates how religious experiences, in this case subjectively perceived encounters with the divine in worship practices, are induced and experienced by believers under the influence of music. Fifteen worship experts (worship leaders and pastors known to engage in this spiritual state in music) were recruited from Pentecostal and charismatic churches. A qualitative model for religious worship, incorporating essence, meaning, music, method, and experience is proposed. It shows that there is not just 'one' religious experience in worship but that there are many of them (a preliminary typology is attempted). There is a feedback loop between the music, the focus on the divine and the mental associations that can strengthen or weaken the experience. The role of music in worship, two approaches to religious experiences (i.e., the sui generis and the attribution theory), and the possibilities for future research are discussed.
\end{abstract}

KEYWORDS: Devotion, Music, Phenomenology of Religion, Religious Experience, Worship.

When asked about specific religious worship experiences, one of the participants in the current research sample expressed the following remarks:

I felt the presence of God permeating the whole room. . . It was so thick that it was almost like you could cut it with a knife. Even until today, I don't understand the full meaning of this experience. But almost every minute, there was a power surge flowing through my body. I can't tell you why. But it felt like a heartbeat was pulsating through me. And the whole thing seemed like this was the heartbeat of God.

Such religious experiences can have a powerful impact on the lives of believers and in some cases they may play a lasting and transformative role where one wishes to invest one's life on a higher cause (Trinitapoli \& Vaisey, 2009). The centrality of religiosity scale CRS (Huber \& Huber, 2012) models a person's religiosity along the five dimensions of intellect, ideology, public practice, private practice and religious experience. Whereas philosophers have given much thought to religion's intellectual and ideological dimensions, sociologists have had a strong focus on public practice and psychologists have been intrigued by private practice

\footnotetext{
${ }^{1}$ Correspondent Author E-Mail: yoshija.walter@gmail.com
} 
(Hood, 1995). The natural and neurological sciences have put an emphasis on mental states (Hick, 2006a), although the biological study of religious phenomena is still in its infancy. So far, empirical research on religious experience is rather scarce.

Religious experience has been described as a 'direct contact to an ultimate reality' (Stark \& Glock, 1968, p. 126) and the inventors of the CRS discern between two forms: (i) one-to-one experiences and (ii) oneness experiences (Huber \& Huber, 2012, p. 715). The first is a dialogical mode where the believer feels to be in conversation and in contact with God or a higher power. The second one is a participative form where the person feels to be in unison or deeply connected to the divine. From the subject's point of view, such extraordinary sensations could be labelled as 'encounters with the divine' and it is uncontroversial that they can be of tremendous relevance to a person having these mental excitations: "... what is happening to a subject's belief system when he has a religious experience is a catastrophic readjustment" (Webb, 1985, p. 85).

However, such experiences can also be more mundane and can be integrated into a person's daily life. This makes the phenomenological study thereof a broad topic that has had difficulties to settle on a generally accepted typological model (Boyatzis, 2001; Hick, 2006b; Stark, 1965). Nevertheless, some fundamental key questions have yet not received their deserved attention, namely how the diversity of religious experiences manifest and how exactly - that is, by what physical and psychological mechanisms - they can be induced. These are the main questions that the current study wants to tackle.

In accordance with newer conceptualizations of the phenomenon, like the interactive religious experience model (Leeuwen \& Elk, 2019), the current study assumes that religious beliefs cause people to seek situations where the impact of a supernatural agent is expected. One of these sought-out situations is the active engagement in worship, where believers often hope to experience an intimate communion with a higher power. This makes worship experiences an ideal case for contributing to disentangle these dynamics in the field of religious experiences.

\section{Theoretical Background: Religious Experience and Worship}

Ever since the publication of William James' classic work The varieties of religious experience (1902), the interest in the phenomenological analyses of such occurrences has been popularized. However, researchers, authors and commentators have had many quarrels about the very idea of religious experience. It is broad and fuzzy, making it difficult to conceptualize and even to agree on something as mundane as defining the necessary terms (Yamane, 1998). Almost a century ago, it has been contested that "There is perhaps no vaguer phrase in contemporary religious thought than 'religious experience', (Aubrey, 1933). Jones (1972) spoke of the 'problem' of religious experience and what makes it difficult to conceptually handle is that there are many kinds of phenomenal occurrences that fit under this umbrella term (Hollenbach, 1952). There is a complexity at play that is intricately affected by the social dynamics between a believer and his or her community (Morris, 2012). Some authors tried to aid empirical research in this field by developing constructs like the Spiritual Experience Index (Genia, 1991) or the Daily Spiritual Experience Scale (Underwood, 2006). To some degree, constructs like these help us to instill the intuition that extraordinary experiences can be made tangible or perhaps even quantized.

Although it appears to be difficult to agree upon an exhaustive definition of religious experience, there seems to be unanimity on the Jamesean notion that they are 'immediate personal experiences' (James, 1902, p. 30). It may be worth noting that in James' classic view, subjectively perceived supernatural experiences are the key constituents of religion by and large. Historically, the major conceptual conflict has lied in the question of whether so-believed divine occurrences are an experiential class in and of their own or whether they are merely 
elevated to a special status through the believer's interpretation. The first approach is called the 'sui generis theory' (Eliade, 1960; Pals, 1987; Studstill, 2000) and the second one is referred to as the 'attributional theory' (Barnard, 1992; Hermans, 2015). On the one hand, if having a religious experience means having a sensation which is unlike any other and cannot be explained by or compared to something of the same sort, then a religious experience is a category in and of itself; a so-called category sui generis. On the other hand, if having a divine experience means that an otherwise ordinary event is singled out and by the sheer force of a believer's interpretation of the facts becomes seen as 'divine' or 'religious', then this special status is attributed to the experience. Psychologically, the former would be a pre-interpretation scenario and the latter would be a post-interpretation one (Antes, 2002; Braley, 2006; Robinson, 2003). These two scenarios entail an interesting question which has captured the attention of authors from a diverse panoply of disciplines: do 'encounters with the divine' carry phenomenal features that 'make' them religious from the very beginning when they are conceived? Or are they rather made 'divine' or 'religious' by a feat of post-hoc interpretation when the human brain integrates the sensations with already held beliefs and when the person tries to make sense of the experience in light of his or her social environment?

Ann Taves $(2005,2009,2011)$ has contributed much to studying this domain and she leans towards an attributional approach where people singularize otherwise 'special' occurrences. By force of interpretation, one deems an experience as religious. Her theory is helpful not only because it creates a bridge between the humanities and social sciences with the cognitive and neurological sciences, but also because it breaks down religious experiences into building blocks. First, Taves differentiates between ascriptions and attributions:

- Ascriptions of qualities: This is how a person subjectively characterizes the inherent qualities of an experience. The experiencer perceives a special nature in the occurrence. Examples: A person may feel unified with the cosmos or with God; one may feel blissful in a worship ceremony; someone may believe to be hearing the voice of a supernatural agent.

- Attributions of causality: These are subjective explanations of causality. The experiencer attributes a special origin and cause to the occurrence. A special quality of an experience may hence stem from the interaction with a supernatural agent or a divine reality.

Examples: A person may think that the cosmos or God reaches out to unify with him/her; one may believe that the Holy Spirit's presence causes a blissful state during a worship ceremony; someone may think that a supernatural agent makes itself noticeable by speaking to the person.

A central concern in this theory is to understand the role and nature of ascriptions, since they play a crucial part in forming what believers hold to be 'experiences deemed religious'. Causal attributions are usually superimposed on an experience after the fact whereas ascriptions can emerge as part of the primary function of an experience. Hence, Taves (2011) discerned between two forms of ascriptions:

- Simple ascriptions: are the conceptions of fundamental experiences as considerably special. This mark of 'specialness' creates the subjective characterization of an event as 'religious' or 'divine'. Examples: A person may feel to be a part of a larger reality; or one may sense the presence of God.

- Composite ascriptions: emerge when two or more simple ascriptions (or: 'things deemed special') are combined to form a larger web of 'special things'. Often, these are 
ideas of how to recreate fundamental, special and hence religious experiences. Examples: Through meditation practices, a person may become part of a lager reality; in worship ceremonies, one may recreate the state of sensing the presence of God.

Taves $(2005,2009,2011)$ referred to the mechanisms of ascribing these marks of specialness to an experience as the process of singularization. This is how a religious experience is generated, namely by being perceived as 'set apart' from ordinary occurrences. If an event is subjectively considered as too extraordinary or too special to belong to the cluster of things we experience in ordinary life, it becomes singled out (singularized) and receives a special value. In other words, it becomes an 'experience deemed religious', a 'divine occurrence' or an 'encounter with God'.

All this means that religious experiences can be studied on different levels. So far, this has mainly occurred under the headings of theories emphasizing the importance of language in the construction of reality through the lenses of relationships, power, and inequalities (Braun, 2011a, 2011b; Jensen, 2003; Regassa, 2017; Sharf, 1998). Likewise, constructivist paradigms have framed the study in the context of race, cultural developments, secularization and as a gendered phenomenon (Collins \& Scott, 2019; Hordern, 2016; Rosado Nunes, 2001; Schnabel, 2018). Although these avenues certainly have their merits, it was correctly criticized that they do not adequately take individual psychological mechanisms into account (Azari et al., 2005) and a better qualitative understanding as well as biometric insights would be helpful (Bender, 2010; McNamara \& Butler, 2013; Paloutzian \& Park, 2013). Taves' analyses provided a valuable contribution to the current study because it offers the theoretical considerations needed to construct a deeper qualitative view of such 'divine experiences' in a way that does justice to the multifaceted nature of such occurrences.

Now there is one context in which such 'encounters with the divine' are not only specifically sought after but also frequently reported. This is the context of individual and ritual worship devotions which is often facilitated by music. It has long been known that music can help with the induction of a religious experience, with some authors calling it a 'trigger' for such events. In her quantitative study, Sarah Demmrich held (2018, p. 35):

\section{Music and religion are linked in many ways. For example, music can trigger religious experiences, which has been a topic since the beginnings of the study of the psychology of religion. [...] Religious experience during music is strongly predicted by positive emotions that are felt during the musical experience.}

These tendencies hold true cross-culturally and across religions (Bohlman et al., 2005; Friedmann, 2010; Gabrielsson, 2011; Weinrich, 2019). For some people, music itself holds transcendent qualities that are inherent to our responses to the well-crafted sound waves (Boyce-Tillman, 2006). However, according to surveys, a transcendent experience is rather something that emerges from our active mental engagement with the music and not something that is intrinsically or extrinsically present in the tonal structures (Atkins \& Schubert, 2014). A study based on factor analyses found that both the employment of music as well as church activities were rated as intense experiences, leaving the authors to conclude that the two experiences may be similar in nature. Although musical items were rated as more intense, the church activities appeared to be connected to an additional factor, namely the sense of a 'transcendent dimension'. This adds to the subjective significance of religious rituals (Hills \& Argyle, 1998). Of course, ritual worship practices combine both of these worlds, making them an intense emotional experience that is connected to something supernaturally meaningful.

One qualitative analysis holds that intense musical experiences are something spiritual and correspond to altered states of consciousness, leaving the people with significant long-term 
effects in their lives. This has a positive effect on a person's perception of meaning of life, social relationships, engagement, activities as well as personal development (Schäfer et al., 2014). Spirituality in such a context has been defined as 'relationality within the musical experience', which implies that we are put in connection with others, with music and thus ultimately with something bigger than oneself (Boyce-Tillman, 2007). This is an important insight which has led to the application of constructs like spirituality in the clinical setting of music therapy (Potvin \& Argue, 2014). Apparently, the "connections between music and both medicine and religious experience are well-established" (Lipe, 2002, p. 209).

In his study of ecstatic experiences through Pentecostalism and popular music, Jennings (2014) concludes that music can elicit ecstatic sensations in both secular and religious contexts. But in any case, they may be theorized as 'proto-religious phenomena' from where a genuine religious experience can develop. If this is true, then Sander van Maas (2009, p. 158) may have some merit in claiming that "a religious experience can be evoked by musical-technical means".

Music as a form of worship has had a long standing in religious traditions and considerably helped forming them. The way the different churches employed their worship songs and the styles they embraced influenced their ecclesiological development as well as how they were viewed from the outside (Hammond, 2014). Likewise, in present church services, the selection of musical styles is relevant for the phenomenal experience. An investigation on Pentecostal music styles and worship practices revealed two interesting results: first, the church members' moods were elevated significantly during the musical worship part as compared to right before and right after. Second, after listening to two religious and two secular songs, the Pentecostals had a stronger positive emotional reaction to the religious songs than the nonPentecostals, although the secular songs were rated equally. This demonstrates how music can be employed as a facilitator of religious experiences and some churches make efficient use of this fact (Miller \& Strongman, 2002). Long ago, it was clear that music can be used as an expression of religious feeling (Andrews, 1916), but this now shows that it also works the other way around: music can be an inducer of 'divine experiences'. As church attendance is in decline in the West, it has hence been argued that pop music and festivals may become a new haven where such experiences can be collected and shared (Kommers, 2011).

Barrett (2017) distinguished between ordinary and extraordinary religious experiences. He highlighted that there is a certain degree of engagement required for a practice to exceed the threshold that an experience would be perceived as extraordinary and divine. For example, in a worship ceremony a person can be bored and just 'singing along' while not really being in a strong mental state of praising God and sensing his presence. Neurologically, both music and religious engagements can elicit intense and extraordinary sensations. In Leonard Meyer's (1961) musicology study, he noted that Beethoven in a C-sharp minor string quartet (Op. 131) continually creates some musical expectations which he intentionally refuses to deliver. When finally, he introduces the listener with some variations of what is expected, it generates a strong sense of satisfaction. According to PET scan analyses, such expectations and peak experiences in music recruit the reward pathways in the human brain (Salimpoor et al., 2011). Although not the exact same regions were activated, an fMRI study among religious Mormons showed that in their devotional practices, euphoric experiences were also correlated with the reward circuitry in the brain (Ferguson et al., 2018). This could explain why various sorts of profound experiences may be phenomenally different but still feel equally engaging, deep and spiritual.

So far, however, the qualitative understanding of the intersection between music and worship at the locus for the induction and engagement with 'experiences with the divine' is dim. Some qualitative modelling attempts are required in order to better understand how subjects use musical worship modes to achieve what they believe to be 'encounters with God' and what types of experiences subsequently emerge. This is where the current study steps in. 


\section{Methodology}

\section{Participants}

The study began with the recruitment of 15 worship experts (6 females; 9 males; 22-39 years of age) in Switzerland ${ }^{2}$. The term worship experts is hereby used loosely since it is supposed to denote believers who obtain a leading role in their respective churches in the worship ceremonies. This means they are either musical worship band leaders or pastors responsible for the worship domain. It was important to select participants who have a high degree of self-reported reproducibility of their own worship experiences. At the same time, they ought to be knowledgeable in the field both theoretically and from their own experiences. By attending services of charismatic churches known for their strong emphasis on music in their worship ceremonies and with a focus on experiential features that are deemed divine, leading figures who conformed to the above-mentioned inclusion criteria were recruited for this study.

Table 1

Characterization of the Study Participants

\begin{tabular}{|c|c|c|c|c|}
\hline participant & $\begin{array}{l}\text { male }(m), \\
\text { female }(f)\end{array}$ & Worship leader & $\begin{array}{c}\text { Pastoral } \\
\text { leadership }\end{array}$ & Musician \\
\hline Participant 1 & $\mathrm{f}$ & $\mathrm{x}$ & & $\mathrm{X}$ \\
\hline Participant 2 & $\mathrm{f}$ & $\mathrm{x}$ & & $\mathrm{x}$ \\
\hline Participant 3 & $\mathrm{~m}$ & $\mathrm{x}$ & & $\mathrm{x}$ \\
\hline Participant 4 & $\mathrm{f}$ & $\mathrm{x}$ & & $\mathrm{x}$ \\
\hline Participant 5 & $\mathrm{~m}$ & & $\mathrm{x}$ & $(\mathrm{x})$ \\
\hline Participant 6 & $\mathrm{f}$ & $\mathrm{x}$ & & $\mathrm{x}$ \\
\hline Participant 7 & $\mathrm{~m}$ & $\mathrm{x}$ & & $\mathrm{x}$ \\
\hline Participant 8 & $\mathrm{~m}$ & & $\mathrm{x}$ & \\
\hline Participant 9 & $\mathrm{~m}$ & $\mathrm{x}$ & & $\mathrm{x}$ \\
\hline Participant 10 & $\mathrm{f}$ & $\mathrm{x}$ & $\mathrm{x}$ & $\mathrm{x}$ \\
\hline Participant 11 & $\mathrm{f}$ & $\mathrm{x}$ & & $\mathrm{x}$ \\
\hline Participant 12 & $\mathrm{~m}$ & $\mathrm{x}$ & & $\mathrm{x}$ \\
\hline Participant 13 & $\mathrm{~m}$ & $\mathrm{x}$ & & $\mathrm{x}$ \\
\hline Participant 14 & $\mathrm{~m}$ & $\mathrm{x}$ & & $\mathrm{x}$ \\
\hline Participant 15 & $\mathrm{~m}$ & $\mathrm{x}$ & & $\mathrm{x}$ \\
\hline
\end{tabular}

\section{Procedure}

A semi-standardized interview outline was constructed which questions revolving around three topics: (i) understanding the varieties of such perceived encounters with the divine, (ii) asking about the place of music in the experience, (iii) and understanding how these phenomenological states are induced, among others, with the help of musical practices.

The interviews took part after a warm-up session of about 20 minutes where the participants were welcomed and asked whether there are any questions about the study. The interviews started only after a friendly "getting to know each other" phase were the subjects fully settled down and expressed to feel comfortable enough. The dialogues were recorded and lasted on average about 40 minutes (min: 23mins; max: 57mins).

\footnotetext{
${ }^{2}$ In order to protect the anonymity of the participants, their geographic, denominational and demographic specificities are not being shared with the public.
} 
The interviews were transcribed and analyzed through a standardized method in qualitative research called inductive content analysis (Mayring, 2015). First, the main topics in the texts were highlighted as main categories. The first-level categories (L1) are topics which are big themes that are relevant for musical worship and its connection to so-called encounters with the divine. The big themes for worship states are essence, meaning, music, method and phenomenal experience. They portray the pillars for the constructed model of worship experiences. By going over the transcripts several rounds, these categories were further refined into sub-categories, sub-sub categories, and so forth. In the main model, first-level categories are called topics, second-level ones are referred to as categories, third-level tiers are known as sub-categories and fourth-level categories are labelled as cases. The latter are named cases because they usually exemplify individual instances that are present in the categories in a more generalized fashion. These categories explain the variance of different approaches believers have towards the phenomenon.

In the natural course of the discussions, the topic experience was touched upon the most with the key categories being phenomenology (which deals with the question which kinds of experiences do worshippers have in the process) and induction (which deals with the question of how such experiences are induced with the help of worship music). The second most discussed topic was music, which revolved around how music is a medium to facilitate such experiences and the role of the melodies as well as the text. The next topic is meaning, asking about what worship means to the participants, followed by the topic method, which asks about how worship is used as a method to induce spiritual experiences. Last but not least, the topic essence was discussed, which deals with how believers conceptualize the very idea of worship. Figure 1 depicts a quantification of the themes based on the counts how often they were referred to in the interviews.

\section{Figure 1}

Tree-Map Quantification of the Main Topics and Categories

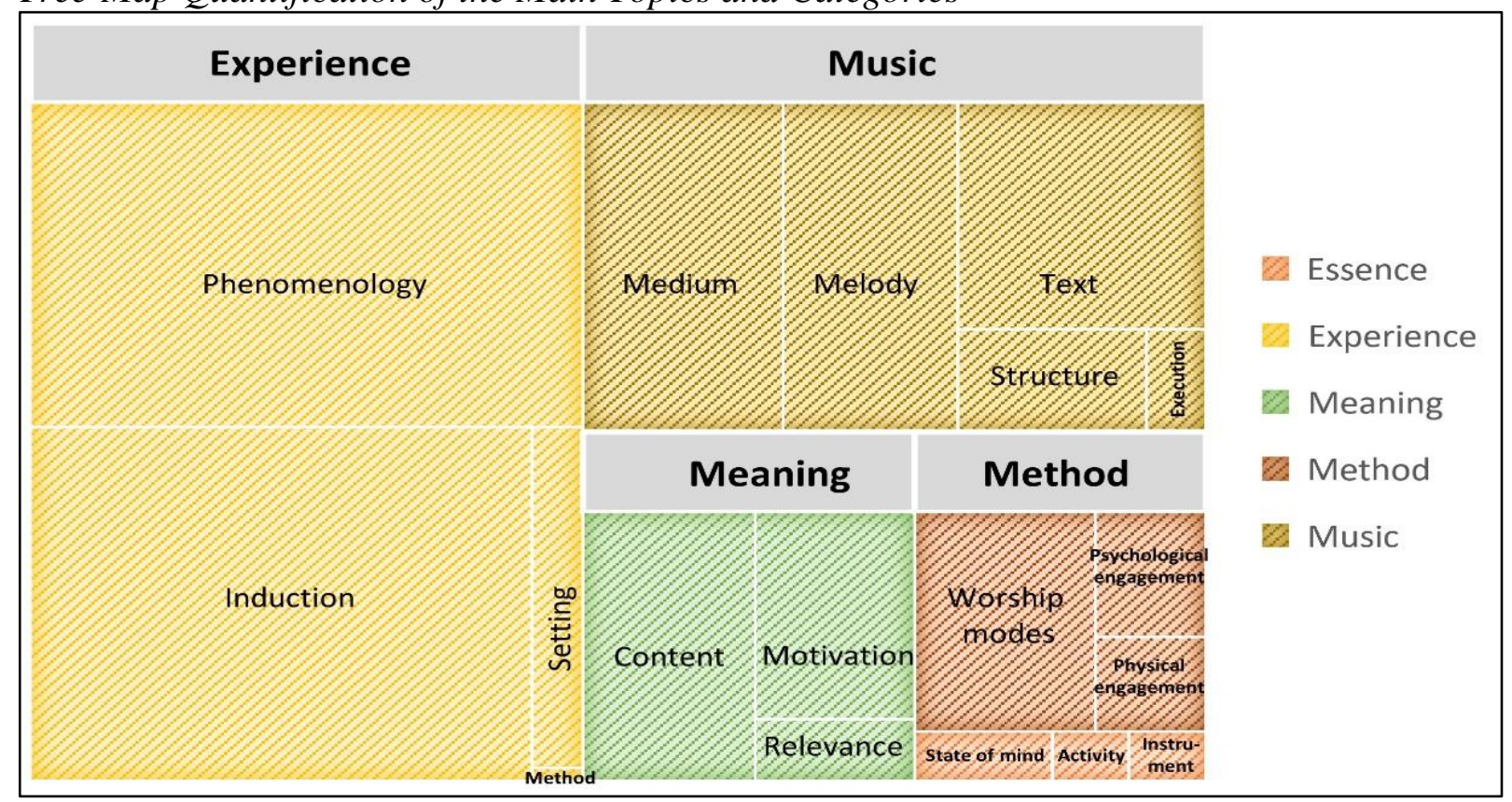

Note. Based on counts in the interviews (cf. detailed category description in the appendix). 


\section{Analysis}

The results were collected in a comprehensive table, which contained all the textual fragments (items) that validated the categories. A further table illustrated how (sub-)categories related to each other. This information was depicted on a graphical model, the typological model for religious worship experiences. With their answers, all participants partially contributed to the formation of the model. As an unintended consequence, the feedback loop model emerged in the process.

Here is a practical example of how the inductive content analysis worked for the creation of the typological model:

An interview question was: "Does music in worship help you to sense the presence of God?" One participant stated: "Yes, I believe that it unleashes an atmosphere [...,] it can influence our emotions." In the transcript, every subject was given a number to protect the person's anonymity and each textual passage which was helpful for the analysis also received a number. If this would have been the first participant and the first passage to be used, then this fragment would be labelled as number 1.1. The second passage from the same person would be numbered 1.2., and so forth. In a first step, categories were gathered and connected to items in the transcript. This particular question was geared towards music in worship and its mediating function. The subject holds that music transports emotions and that it creates an atmosphere beneficial for the experience. The steps would look like this:

\section{Table 2}

Category creation

\begin{tabular}{ll}
\hline Item Categories \\
\hline
\end{tabular}

1.1 . music, medium, transports emotions, creates an atmosphere

Note. Gathering the categories from the text.

In this example, potential categories and subcategories can be distinguished:

Table 3

Theme creation

\begin{tabular}{lcc}
\hline Item & Potential Categories & Potential subcategories \\
\hline 1.1. & Music, medium & Transports emotions, creates an atmosphere \\
\hline
\end{tabular}

Note. Splitting overarching themes from underlying categories.

As more data from interview participants accumulates, further categories enter the stage, understanding of what these categories mean becomes enriched and it becomes evident which categories are more general and which of them are more specific instances, thereby explaining the variance of the more general ones. Now here are two kinds of tables emerging: first, a table that explains where categories can be found in the text and second, one that deals with what categories there are and how they relate to one another. The first would look like this:

Table 4

Category Hierarchy

\begin{tabular}{lllll}
\hline Item & Topic & Category & Subcategory & Case \\
\hline 1.1. & Music & Medium & Transports emotions & atmosphere \\
\hline
\end{tabular}

Note. Emergent hierarchy of categories. 
When we look across the board and take other passages and subjects into account, we see that there are more cases where music can transport emotions as a medium for facilitating worship experiences.

Table 5

Enrichment

\begin{tabular}{|c|c|c|c|}
\hline Topics & Categories & Subcategories & Cases \\
\hline \multirow[t]{2}{*}{ Music } & Medium & Transports emotions & Atmosphere \\
\hline & & & $\begin{array}{l}\text { Correspondence with } \\
\text { psychological state } \\
\text { Correspondence with } \\
\text { past memories } \\
\text { Self-expression }\end{array}$ \\
\hline
\end{tabular}

Note. The subcategory is enriched with further cases from the same or other subjects.

The typological model tries to make these dynamics more intuitively understandable by depicting them graphically:

\section{Figure 2}

Category relations

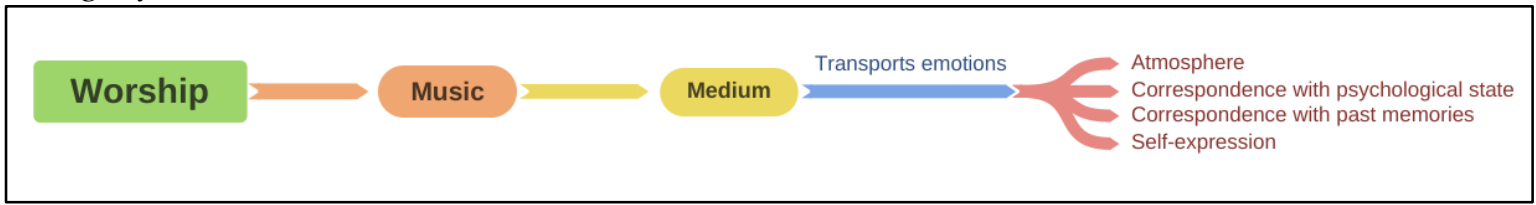

Note. Graphic example of how inductive categories relate to one another.

As more interviews are analyzed, more topics, categories, subcategories and cases emerge. Eventually, one arrives at the typological model as seen below. Every participant contributes their parts to the construction of the model and together they can help explain the variance inherent in the phenomenon.

\section{Results}

Overview

(Please see next page) 
Figure 3

Typological Model for Religious Worship States in Relation to Musical Practices.

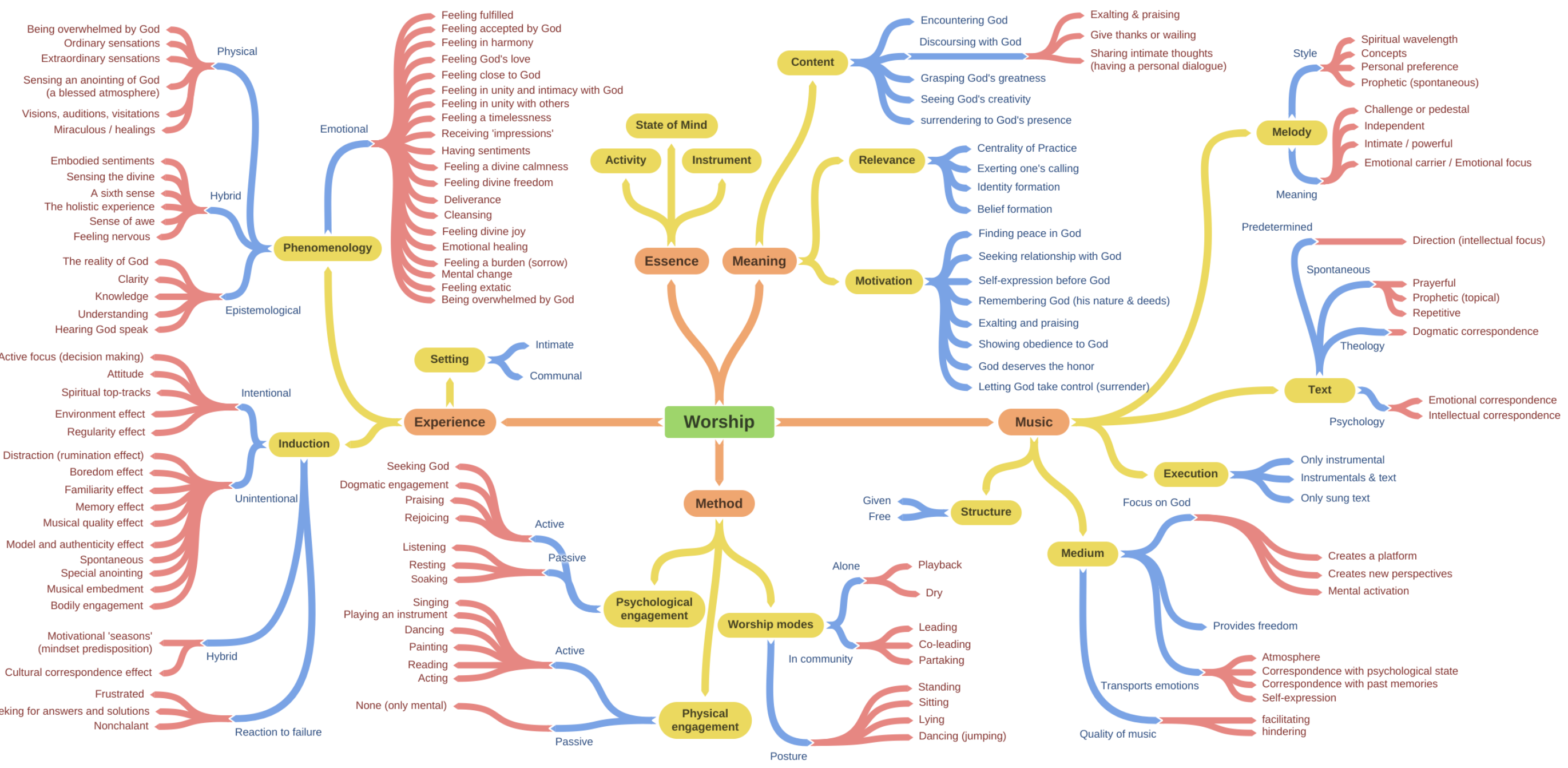


Usually, these cases can take up certain values, which can either take the form of valence, frequency or both.

\section{Table 6}

Summary of Possible Case Values by Valence and Frequency
Valence
a) Directed inwardly (introspection)
b) Directed outwardly (extrospection)
c) Directed towards God (theocentric extrospection)

\begin{tabular}{ll}
\hline \multicolumn{2}{l}{ Frequency } \\
\hline i) Frequent experience (close) \\
ii) Rare experience (far)
\end{tabular}

\section{Figure 4}

Feedback Loop Model for Religious Worship Experiences

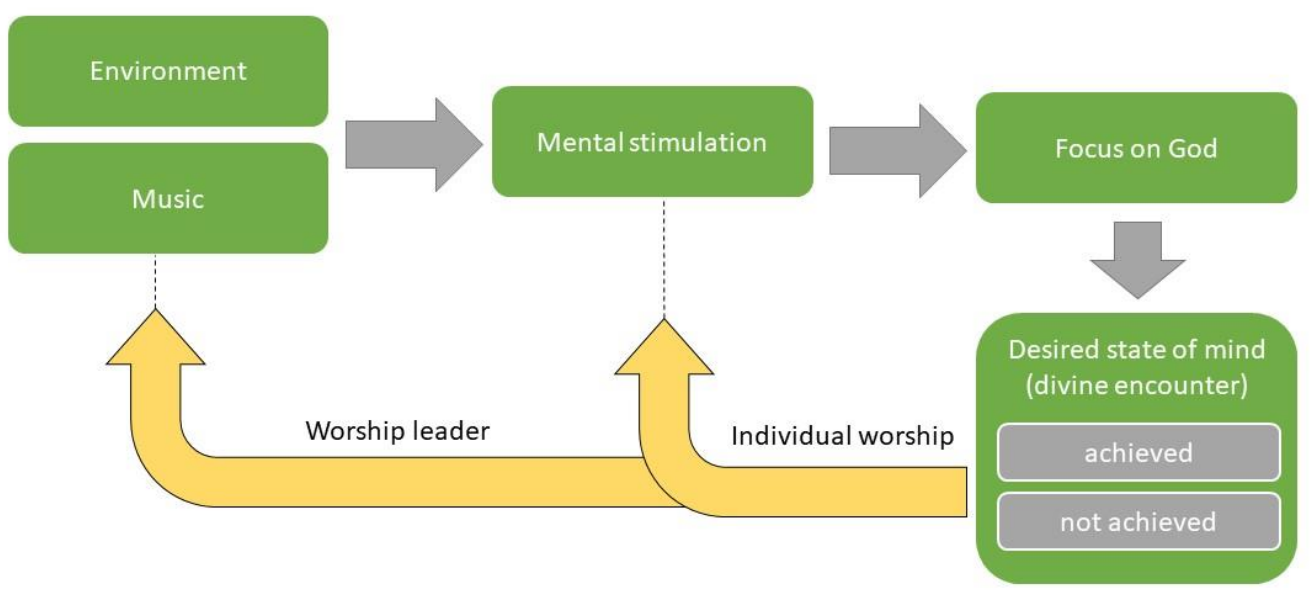

The main findings are depicted in Figure 3, however, no single participant delivered all of the categories visible in the image. Instead, each of them provided a puzzle piece to the picture at large and the model as a whole help to explain the variance of how believers perceive their worship experiences and how they engage with them. A full description of each category is found in the appendix.

\section{Global Mechanisms in Worship}

The feedback loop model emerges from the data as an unexpected finding. It portrays the dynamics of how music and the environment can foster and indeed provoke a subjectively perceived divine encounter in the context of worship. It was not intended to introduce a new framework to think about religious experiences in worship but to enrich the present views with a deeper understanding about the varieties of religious experience and with the knowledge of how they can be induced by the experiencers. However, it has become clear in the course of the current study that external factors (i.e. music and environmental elements) can provoke a certain mindset that helps people focus on God, which in turn helps with the induction of the desired worship experience. This interplay of the mental stimulation of a person and the focus on God is important. The better a person can focus on God, so it seems, the more likely it becomes that one feels in contact with the divine and this means that the person is then more receptive to 
such an extraordinary experience. This is in accordance with the interactive religious experience model (Leeuwen \& Elk, 2019) which holds that believers seek for situations where they can expect to have an encounter with a higher power. The case of worship experiences is a perfect example thereof. The feedback loop model adds to this that the believer is likely to achieve this state of mind when he or she can focus on God, which is itself malleable by environmental and musical factors. As one participant expressed: "Musical worship is something that helps me to open up. That's probably why I experience God more in a worship context than outside of it."

As seen in exhibit 4, there is an interesting trend that emerges from the statements of the present worshippers: at the beginning it seems like there is a causal relationship from the musical environment to the divine experience where people believe to be in an encounter with God. First, the causal chain starts with a positive and facilitating environment which can be achieved by a musical atmosphere where the participants feel comfortable. This should help subjects to warm up with the eventual goal to mentally open up and focus on God. Therein, God becomes the addressee of the believer's exaltation, thanks and praise. As a result, the worshipper attempts to be receptive for the experiences that are believed to originate from a supernatural source. From here, either a negative or a positive feedback loop can emerge. When one has pleasant sensations, this can positively reinforce one's worship practice and the focus on God which eventually can strengthen the downstream experience of communion with the higher power. In the case of communal worship where the worshipper is leading the ceremony, positive experiences can have an impact on the intensity of playing music which may affect the community's collective focus on God and can lead to shared spiritual sensations in the worship endeavor. An unpleasant experience can occur when a person's expectations remain unfulfilled and this can also negatively impact a person's mood and focus, which could eventually terminate the desired divine experience. For example: a person may have high expectations to sense the presence of God in a worship ceremony but somehow this does not happen. The experience is not as exciting as was hoped for and it diminishes the motivation to further participate in the worship atmosphere. As a consequence, the focus is diverted and the experience will lessen continually. When the motivation sinks below a subjective threshold, then the person ceases to actively engage in the worship and praise mentality. However, this natural spiral can be counteracted by a conscious decision to subvert the emotional state of mind through an intellectual effort. Rather than already sensing a divine presence, the person actively makes a decision to set the focus on God despite the difficult emotional circumstances. At times, this can lead to the desired state of mind where a divine presence is perceived. But without the musico-emotional support, it does not always work. However, the reverse is also true: simply having music in the background without actively engaging with it and using it to help focusing on God does often not elicit a mental response that would be labelled as a religious experience.

Although the feedback-loop model in exhibit 4 portrays some valuable trends, it does not depict the full truth because it works with some oversimplifications. The facilitating effects of music can be seen in the following quote by one of the worship leaders in the sample:

For me, music creates an emotional framework, this emotional mood, where I feel secure and relaxed. I feel welcomed to seek for an encounter with God. In other moments of my daily life, I am not equally in a state of mind where I seek after God, because there are many distractions, or I simply don't feel like it. But music creates a stillness in my thoughts and in my spirit so that I can turn off and calm down. Then I don't have to perform anymore like I usually do. Music leads me into a state where I feel free and where I hence have the capacity to search for God. 
It sounds like music is a tool for putting the focus on God and this then in turn can elicit a divine experience. However, this description falls short of an important feature. Music is not correctly portrayed as merely an auxiliary tool leading to an expression of worship. As some participants have emphasized, music is worship expression. And as such, at times it is the divine worship experience. One subject stated,

\begin{abstract}
In my view, music is much more than a tool. Music is an expression of God's creativity through humans. And if we should call it a tool, then it is his and not mine. He can inspire me to make music. Worship is an expression. And then to experience God is the consequence of worship. First and foremost, worship means looking at God; or focusing on him. ... And this is why I would claim that it's not a tool but in fact a very part of the communication itself - in both directions.
\end{abstract}

Since music employed as a means for worship is not merely a tool for exciting a mental state but in fact can itself be a form of communication with the divine and reverse, in this mental appropriation it is more than just music. As seen before, music - be it secular or religious - can elicit intense subjective responses. But here, it can coincide with a broad array of cognitive concepts and emotional sensations. This might enrich an already intense experience with higher levels of meaningfulness. When one participant was asked about the difference between experiencing a secular song and a worship song, she explained that a secular song can be a pleasant experience, but it can never go as deep. A worship song activates the whole essence of a person and resonates with one's whole being. In a sense, one might say that there are added dimensions to the song. Perhaps on a neurological note, there might be a much stronger degree of higher order integration with a worship song as opposed to a secular one. Yet again, it is worthy to note that many subjects reported that as long as they were in the right mind frame, they could actively worship to any song. Hence, even a secular song can be transformed into a worship song.

\title{
Modelling the Musical Worship Experience
}

As Figure 3 shows, a devotional worship practice can be modelled along five big topics. The first of these is essence and it deals with the core of what worship is supposed to be in the believer's eyes. Worship can be seen as an activity, a state of mind or as an instrument to come closer to God. The topic meaning explains the main function of worship experiences in terms of their content (i.e., the idea that one encounters God or surrenders to his presence), relevance of the practice, and motivation for engaging in the experience. The subcategories in our model tell us what the categories consist of. For example: "finding peace in God" (subcategory) is one possible "motivation" (category) for doing worship. One important element to the practice is, of course, the music itself. It can be studied in respect to the melody (either by its cognitive meaning or its style) and in respect to the text, which can be spontaneous or predetermined. The text can be reflected in light of its theology or how strongly it conforms to a person's psychological predispositions. The music can be executed either with or without singing or instruments. In the whole worship endeavor, music is supposed to be a medium. First and foremost, it helps believers to focus on God. It does so by transporting emotions which is determined, among other things, by the quality of music and how much it corresponds to a person's tastes and psychological predispositions. The structure of a song can then be completely free or it can be a given song with a clear liturgy. Depending on the person, usually one is favored over the other.

There are three ways in which the worship practice can act as a method in order to get closer to the perceived divine. First, there are particular worship modes, meaning that one can 
enact the rituals by oneself or in community, and with specific postures (like standing, sitting, lying on the floor or dancing). Second, the experience can come along with some physical engagement (i.e., painting, reading, or acting). Third, it occurs with psychological engagement, which can take place in an active or a passive fashion. The active fashion entails that one can use the worship ritual to seek God, reflect upon one's beliefs (dogmatic engagement), to praise him, and to rejoice. On the passive note, one can be merely listening, resting or soaking (which is the deliberate idea to "soak up the presence of God").

Perhaps the most interesting topic is experience which takes place in two settings: either intimately or communally. The first is that a person believes to be connected to the divine in a one-to-one fashion, regardless of whether one worships alone or in community. The second is the opposite kind of experience: it is when a person feels one with others in the room and simultaneously with God. There are different phenomenal types of experience which believers can achieve. They can be purely emotional, like feeling fulfilled, feeling accepted by God, feeling in harmony, etc. Let's consider the state of feeling fulfilled as one interviewee described it vividly:

\begin{abstract}
One of the most beautiful things I have ever experienced was this fulfillment. I can remember it palpably, it was at a worship event. I felt so fulfilled that I thought: if God would say to me: "Now that's all. This is all that I have for you. It will not get any better than this. This is the climax." Then I thought to myself: it is good. I would not lack a single thing in this moment. Absolutely nothing. This is a very intense experience. It's something completely unusual. Especially because we live in a society where we are not allowed to be fully content. If you think you have it, then you have somehow failed in setting high aspirations. ... But I had this complete sensation of: I am perfectly well, I don't need anything more to be content.
\end{abstract}

Worshippers also frequently report physical experiences, which they sometimes refer to as manifestations. This is when the body reacts to an apparently spiritual phenomenon. One can be overwhelmed by God and hence lose strength and fall to the floor. One can have ordinary sensations (i.e., feeling energized) or extraordinary sensations (i.e., feeling the power of God like an electrical current on the skin). Hybrid experiences have both an emotional and a physical aspect to them. Consider the following example to get an idea of how hybrid phenomena are sometimes described:
In the moment when the pastor entered the stage and we were starting to pray, there was a power that came from outside. As if you were plunged into a force field so that I had to grab something to steady myself - luckily, the piano was right behind me. Otherwise I probably would have fallen to the ground. ... It was vibrant; something that was affecting me from the outside. It resonated with my whole being so that I got goose bumps and my knees got weak. ... And it's also very emotional because you realize that it's supernatural.

Last but not least, there may be epistemological experiences. This is when worshippers report to have a sudden clarity or knowledge about the divine as a result of worship practices.

There are several ways in which such an experience can be induced, which is either intentional or unintentional. In the intentional scheme, the main method is to actively decide to focus on God and hence "let him in". This has to do with one's attitude and can be aided with spiritual top-tracks (these are songs that a subject knows work particularly well to get into the 
right mood). The environment effect states that the surroundings can aid in the experience (i.e., dim lights) and the regularity effect holds that the songs that are played often are already wellknown and hence are easy to be employed for the experience. There are also some unintentional induction modes. One is the rumination effect which states that when a person is distracted, it is difficult to focus on God. The boredom effect has the same result but only because one is literally bored by the music. The familiarity effect can go in both ways: the better one knows the song, the more one is free to focus on God but if the music is too familiar, it can turn the other way and get boring. The same tendencies occur with the memory and the musical quality effect. If a worship leader on the stage acts as an inspirational catalyst, then this would be a case for the model and authenticity effect. Such experiences often come spontaneously and are sometimes considered a form of special anointing (a blessing lying on the season or in the room). If the atmosphere is well embedded in the music or if there is some bodily engagement, it can be helpful to induce such an experience.

There hybrid inductions that can be used both intentionally as well as unintentionally. One is the idea of motivational seasons. This means that at times a group's predisposition of the mind is simply easier to be recruited than at others. Another one is the cultural correspondence effect, which is the notion that some worship styles are more in harmony with the subculture of a group than others. But this, of course, varies over time since there is an evolution in every (sub-)cultural development.

Sometimes a worshipper is not successful, meaning that one has to deal with the fact that even though one is engaging in a worship practice, one does not sense something divine. There are several reactions to this so-called failure of the desired state of mind. Generally, believers report to be frustrated because they often enter their devotions in the hopes of getting closer to God. If the person then does not sense the divine or have a special experience, then it often feels anticlimactic. Some are more pragmatic and try to search for a solution: "What is wrong? Where is the problem?" They want to fix the issue so that eventually they still manage to elicit a divinely inspired response. But not all respondents are always frustrated. People who practice this a lot may learn to accept it as a fact of life that one cannot always have such an experience. They enjoy the practice nonetheless.

\section{Discussion}

\section{Theoretical Reflections: Sui Generis or Attribution?}

At the beginning of this paper, it was discussed that there is a conceptual discrepancy between theories that describe religious experience as a class in and of its own and theories that describe it as an attributive phenomenon. In the first scenario, there is something unique about such kinds of experiences so that they cannot be reduced and compared to other mental states. It is like the perception of the color red which cannot be compared to the smell of a perfume. The two are phenomenally different types of sensations. However, claiming that it is human interpretation which makes an experience religious or divine means that it is in principle an experience like any other. It would be only the attribution - or, in other words, the subject's interpretation - which is responsible for differentiating extraordinary from ordinary events. What can we learn from the subjects in this study?

At first sight, it appears as though the current data is inconclusive about this question because it affirms both tendencies. On the one hand, a number of participants make a strong case that what they sometimes experience cannot be put into ordinary words. It comes close to what they would refer to as a sixth sense. Apparently, it feels like an experience with otherworldly qualities. At times, a certain occurrence may emerge with a strong clarity and knowledge that the event originates from God. Such descriptions offer the notion that they do not require additional interpretation because the feeling that the experience is divine is 
automatically forced upon the experiencer. On the other hand, there are so-called divine experiences in worship that can be perfectly explained in natural terms. And some subjects even hold that in these cases, it is the religious context that makes it evident to them that this is a special event. This seems like a theoretical impasse between the sui generis and the attribution approach.

However, it may not be the full story. The typology of worship experiences from the model in Figure 3 suggests that there is not just one kind of experience at play. There are different kinds of them and at times they can coincide and create a wholly new phenomenal state. The "sui generis versus attribution question" makes the crucial mistake that it acts as though there was only one type of religious experience. But what if there is not the religious experience but a panoply of them? Then the theoretical question would not be an either-or situation. In this case, it would be much more plausible to conceive of these two theories as criteria on a spectrum. Some events may be completely unique and inherently religious whereas others are not but can still be perceived as divine depending on the context. This means that some experiences may be more or less special to the perceivers (cf. Taves, 2011) which in turn requires them to have more or less added interpretation to the phenomenon in order to be viewed as religious or divine. In fact, this is what we find in our sample and it is made possible by the fact that there is not the religious experience in worship but many different kinds of them. As such, an experience where a believer has an ineffable sixth sense could be called a sui generis experience. But an event where one feels energized by God only in the worship ceremony could be called an attributed phenomenon.

\section{Conclusion \& Study Limitations}

The current study concurs that there is not the religious worship experience but that they can take many forms. One of the main features for a successful induction is that the worshipper manages to actively focus on God and to get in the mood of "letting go" while giving in to the experience. There is an element of spontaneity where one never knows beforehand if such a sobelieved divine experience will occur and what form it will take. As such, it is believed to be entirely in God's hands and out of one's control. But since the active focus is a key element in the induction process, music can act as a considerable support in the facilitation of the experience. However, this is only true if the music is subjectively associated with positive ideas and emotions. If the reverse is the case, then it counteracts the desired states.

In this investigation, 15 proficient worship experts (worship leaders and pastors) were selected, each of them having a rich history of experience, personal knowledge and investment in the topic. There are four domains where no knowledge can be drawn from the present analysis and where it would be interesting to conduct further studies:

First, this study performed an analysis purely on a Christian sample. Hence, it is unclear whether there would be different categories and relationships among them if one would conduct an interreligious study. Second, the focus has lied on a qualitative assessment of the nature of religious worship experiences based on expert interviews of practitioners in the field. As it is the nature of qualitative studies, no quantitative associations in the described categories can be drawn. It would, however, be interesting to enrich this understanding with a quantitative analysis. Third, in order to get the best qualitative understanding of the categories at hand, experts have been interviewed that are known to have had such experiences. Thus, we can now only know how such experiences look like and can be induced by proficient worshippers. But it cannot be answered whether the experience of experts versus laymen considerably differs when it comes to the field of religious worship experiences. This is question that could be tackled in a future study. Fourth, the present research gives us some information about the psychological mechanisms of religious experiences in worship - nothing more and nothing less. However, in the modern era of medical understanding, it would be very interesting to see if 
biometric correlations could be found when subjects are allegedly encountering the divine in worship. Music could act as a facilitator for the experience and with the practice of worshipping, one would have some useful conditions for manipulating the conditions in the lab. Like this, both neural and peripheral-physical processes may be studied.

As such, the present study lays the foundation for interesting future research in the domain of religious experience in worship, especially for the construction of cognitive and phenomenological biometric experiments.

\section{Acknowledgments}

I thank all the participants for being willing to engage in a study that touches on a subject which is very sensitive and intimate to all of them.

\section{References}

Andrews, G. W. (1916). Music as an expression of religious feeling. The Musical Quarterly, II(3), 331-338. https://doi.org/10.1093/mq/II.3.331

Antes, P. (2002). What do we experience if we have religious experience? Numen, 49(3), 336342.

Atkins, P., \& Schubert, E. (2014). Are spiritual experiences through music seen as intrinsic or extrinsic? Religions, 5(1), 76-89. https://doi.org/10.3390/rel5010076

Aubrey, E. E. (1933). The authority of religious experience re-examined. The Journal of Religion, 13(4), 433-449.

Azari, N. P., Missimer, J., \& Seitz, R. J. (2005). Religious experience and emotion: Evidence for distinctive cognitive neural patterns. International Journal for the Psychology of Religion, 15(4), 263-281. https://doi.org/10.1207/s15327582ijpr1504_1

Barnard, G. W. (1992). Explaining the unexplainable: Wayne Proudfoot's "religious experience." Journal of the American Academy of Religion, 60(2), 231-256.

Barrett, N. F. (2017). Ordinary religious experience, learning and adaptation: A call for interdisciplinary inquiry. Palgrave Communications, 3(1), 1-4. https://doi.org/10.1057/palcomms.2017.61

Bender, C. (2010). The new metaphysicals: Spirituality and the American religious imagination. The University of Chicago Press.

Bohlman, P. V., Blumhofer, E., \& Chow, M. (Eds.). (2005). Music in American Religious Experience. Oxford University Press.

Boyatzis, C. J. (2001). A critique of models of religious experience. International Journal for the Psychology of Religion, 11(4), 247-258. https://doi.org/10.1207/S15327582IJPR1104_04

Boyce-Tillman, J. (2006). Music as spiritual experience. Modern Believing, 47(3), 20-31. https://doi.org/10.3828/MB.47.3.20

Boyce-Tillman, J. (2007). Spirituality in the musical experience. In L. Bresler (Ed.), International handbook of research in arts education (pp. 1405-1424). Springer Netherlands. https://doi.org/10.1007/978-1-4020-3052-9_96

Braley, J. (2006). Mysticism, anomaly, and theology: Revisiting Wieman's "Rreligious experience and scientific method." American Journal of Theology \& Philosophy, 27(1), $32-55$.

Braun, W. (2011a). Exprience. In T. Fitzgerald \& R. T. McCutcheon (Eds.), Guide to the study of religion (pp. 125-139). Continuum.

Braun, W. (2011b). Religion. In T. Fitzgerald \& R. T. McCutcheon (Eds.), Guide to the study of religion (pp. 3-20). Continuum. 
Collins, M. E., \& Scott, J. C. (2019). Intersection of race and religion for youth in foster care: Examining policy and practice. Children and Youth Services Review, 98, 163-170. https://doi.org/10.1016/j.childyouth.2019.01.003

Demmrich, S. (2018). Music as a trigger of religious experience: What role does culture play? Psychology of Music, 48(1), 35-49. https://doi.org/10.1177/0305735618779681

Eliade, M. (1960). Myths, dreams and mysteries (translated by Philip Mairet). Harper \& Bros.

Ferguson, M. A., Nielsen, J. A., King, J. B., Dai, L., Giangrasso, D. M., Holman, R., Korenberg, J. R., \& Anderson, J. S. (2018). Reward, salience, and attentional networks are activated by religious experience in devout Mormons. Social Neuroscience, 13(1), 104-116. https://doi.org/10.1080/17470919.2016.1257437

Friedmann, J. L. (2010). Music and Jewish religious experience: Social and theological essays. VDM Verlag.

Gabrielsson, A. (2011). Music and religious experiences. In A. Gabrielsson (Ed.), Strong experiences with music: Music is much more than just music (pp. 171-189). Oxford University Press. https://doi.org/10.1093/acprof:oso/9780199695225.001.0001

Genia, V. (1991). The spiritual experience index: A measure of spiritual maturity. Journal of Religion and Health, 30(4), 337-347.

Hammond, S. L. (2014). To sing or not to sing? Music and the religious experience from 1500 - 1700. The International Journal of Religion and Spirituality in Society, 3(3), 67-76. https://doi.org/10.18848/2154-8633/CGP/v03i03/51065

Hermans, C. A. M. (2015). Towards a theory of spiritual and religious experiences: A building block approach of the unexpected possible. Archive for the Psychology of Religion, 37(2), 141-167. https://doi.org/10.1163/15736121-12341306

Hick, J. (2006a). The neurosciences' challenge to religious experience. In J. Hick (Ed.), The new frontier of religion and science: Religious experience, neuroscience, and the transcendent (pp. 55-66). Palgrave Macmillan UK. https://doi.org/10.1057/9780230626430_5

Hick, J. (2006b). What is religious experience? In J. Hick (Ed.), The new frontier of religion and science: Religious experience, neuroscience, and the transcendent (pp. 27-38). Palgrave Macmillan. https://doi.org/10.1057/9780230626430_3

Hills, P., \& Argyle, M. (1998). Musical and religious experiences and their relationship to happiness. Personality and Individual Differences, 25(1), 91-102. https://doi.org/10.1016/S0191-8869(98)00004-X

Hollenbach, J. W. (1952). The novel as a religious experience. Christian Education, 35(1), 44 57.

Hood, R. W. (1995). Handbook of religious experience (p. 661). Religious Education Press.

Hordern, J. (2016). Religion and culture. Medicine, 44(10), 589-592. https://doi.org/10.1016/j.mpmed.2016.07.011

Huber, S., \& Huber, O. W. (2012). The Centrality of Religiosity Scale (CRS). Religions, 3(3), 710-724. https://doi.org/10.3390/rel3030710

James, W. (1902). The varieties of religious experience (Centenary Ed.). Taylor \& Francis.

Jennings, M. (2014). Exaltation. Peter Lang. https://doi.org/10.3726/978-3-0351-0682-4

Jensen, J. S. (2003). The study of religion in a new key: Theoretical and philosophical soundings in the comparative and general study of religion. Aarhus University Press.

Jones, J. W. (1972). Reflections on the Problem of Religious Experience. Journal of the American Academy of Religion, 40(4), 445-453.

Kommers, H. (2011). Hidden in music: Religious experience and pop festivals. The Journal of Religion \& Popular Culture, 23(1), 14-26. https://doi.org/10.3138/jrpc.23.1.14

Leeuwen, N. V., \& Elk, M. van. (2019). Seeking the supernatural: The interactive religious experience model. Religion, Brain \& Behavior, 9(3), 221-251. https://doi.org/10.1080/2153599X.2018.1453529 
Lipe, A. W. (2002). Beyond therapy: Music, spirituality, and health in human experience: A review of literature. Journal of Music Therapy, 39(3), 209-240. https://doi.org/10.1093/jmt/39.3.209

Maas, S. van. (2009). The reinvention of religious music: Olivier Messiaen's breakthrough toward the beyond. Fordham University Press.

Mayring, P. (2015). Qualitative inhaltsanalyse: Grundlagen und techniken (12., rev. ed.). Beltz Verlag.

McNamara, P., \& Butler, P. M. (2013). The neuropsychology of religious experience. In R. F. Paloutzian \& C. L. Park (Eds.), Handbook of the psychology of religion and spirituality (2nd ed., pp. 215-233). The Guilford Press.

Meyer, L. B. (1961). Emotion and Meaning in Music. University of Chicago Press.

Miller, M. M., \& Strongman, K. T. (2002). The emotional effects of music on religious experience: A study of the Pentecostal-charismatic style of music and worship. Psychology of Music, 30(1), 8-27. https://doi.org/10.1177/0305735602301004

Morris, J. (2012). Secularization and religious experience: Arguments in the histroriography of modern british religion. The Historical Journal, 55(1), 195-219. https://doi.org/10.1017/S0018246X11000598

Paloutzian, R. F., \& Park, C. L. (Eds.). (2013). Recent progress and core issues in the science of the psychology of religion and spirituality. In Handbook of the psychology of religion and spirituality (2nd edition, pp. 3-22). The Guilford Press.

Pals, D. L. (1987). Is religion a sui generis phenomenon? Journal of the American Academy of Religion, LV(2), 259-284. https://doi.org/10.1093/jaarel/LV.2.259

Potvin, N., \& Argue, J. (2014). Theoretical considerations of spirit and spirituality in music therapy. Music Therapy Perspectives, 32(2), 118-128. https://doi.org/10.1093/mtp/miu022

Regassa, M. (2017). Females' Voice through Oral Poetry among Limmuu Oromo, Ethiopia. Journal of Ethnic and Cultural Studies, 4(2), 28-40.

Robinson, D. N. (2003). How religious experience "works": Jamesian pragmatism and its warrants. The Review of Metaphysics, 56(4), 763-778.

Rosado Nunes, M. J. F. (2001). Religion and gender. In N. J. Smelser \& P. B. Baltes (Eds.), International encyclopedia of the social \& behavioral sciences (pp. 13034-13037). Pergamon. https://doi.org/10.1016/B0-08-043076-7/04067-5

Salimpoor, V. N., Benovoy, M., Larcher, K., Dagher, A., \& Zatorre, R. J. (2011). Anatomically distinct dopamine release during anticipation and experience of peak emotion to music. Nature Neuroscience, 14(2), 257-262. https://doi.org/10.1038/nn.2726

Schäfer, T., Smukalla, M., \& Oelker, S.-A. (2014). How music changes our lives: A qualitative study of the long-term effects of intense musical experiences. Psychology of Music, 42(4), 525-544. https://doi.org/10.1177/0305735613482024

Schnabel, L. (2018). More religious, less dogmatic: Toward a general framework for gender differences in religion. Social Science Research, 75, 58-72. https://doi.org/10.1016/j.ssresearch.2018.06.010

Sharf, R. H. (1998). Experience. In M. C. Taylor (Ed.), Critical terms for religious studies (pp. 94-115). University of Chivago Press.

Stark, R. (1965). A taxonomy of religious experience. Journal for the Scientific Study of Religion, 5(1), 97. https://doi.org/10.2307/1384259

Stark, R., \& Glock, C. Y. (1968). American piety: The nature of religious commitment. Berkeley University Press.

Studstill, R. (2000). Eliade, phenomenology, and the sacred. Religious Studies, 36(2), 177-194. https://doi.org/10.1017/S0034412500005175

Taves, A. (2005). Religious experience. In Encyclopedia of religion (2nd ed.). Thompson-Gale. 
Taves, A. (2009). Rereading the varieties of religious experience in transatlantic perspective. Zygon(r), 44(2), 415-432. https://doi.org/10.1111/j.1467-9744.2009.01006.x

Taves, A. (2011). Religious experience reconsidered: A building-block approach to the study of religion and other special things. Princeton University Press.

Trinitapoli, J., \& Vaisey, S. (2009). The transformative role of religious experience: The case of short-term missions. Social Forces, 88(1), 121-146. https://doi.org/10.1353/sof.0.0223

Underwood, L. G. (2006). Ordinary spiritual experience: Qualitative research, interpretive guidelines, and population distribution for the daily spiritual experience scale. Archive for the Psychology of Religion, 28(1), 181-218. https://doi.org/10.1163/008467206777832562

Webb, M. O. (1985). Religious experience as doubt resolution. International Journal for Philosophy of Religion, 18(1-2), 81-86. https://doi.org/10.1007/BF00142282

Weinrich, I. (2019). Sensing sound: Aesthetic and religious experience according to al-Ghazālī. entangled religions. Senses, Religion and Religious Encounter (Vol. 10). https://doi.org/10.13154/ER.10.2019.8437

Yamane, D. (1998). Experience. In W. H. Swatos \& P. Kivisto (Eds.), Encyclopedia of religion and society (pp. 179-182). Alta Mira Press.

\section{Notes on Contributor}

Yoshija Walter has a nuanced academic background in the fields of business economics and management, religious studies, philosophy and neurobiology incl. cognitive biopsychology. He is currently researching the modalities, psychological underpinnings and biological mechanisms of religious worship experiences. The present publication is part of a larger work, which tries to disentangle the different aspects and foundational concepts involved in such perceived transcendent experiences.

Manuscript received January 23, 2021

Final revision received March 18, 2021

Accepted March 20, 2021 


\section{Appendix}

\section{Category Description \& Coding Guidelines}

\section{Level Descriptions}

\begin{tabular}{|c|c|c|}
\hline Level & Label & Description \\
\hline Level 1 (L1) & Topics & $\begin{array}{l}\text { The first-level tiers are the categories that depict the broad spectrum of how worship practices and } \\
\text { experiences can be clustered. These are the big topics which revolve around the phenomenon. }\end{array}$ \\
\hline Level 2 (L2) & Categories & $\begin{array}{l}\text { On the second level there are the categories which depict how the topics can be explained. Taken } \\
\text { together, the categories tell us how the topics work. }\end{array}$ \\
\hline Level 3 (L3) & Subcategories & $\begin{array}{l}\text { The third-level tiers exemplify how the categories can look like and how we find them applied in a } \\
\text { more specific manner. The subcategories do not exhaust all possibilities for how the categories can } \\
\text { manifest but they depict how the participants incorporate the categories in their lives. }\end{array}$ \\
\hline Level 4 (L4) & Cases & $\begin{array}{l}\text { The fourth level is the most specific one. Here we find the cases which are concrete examples of how } \\
\text { the subjects in the sample translate the dynamics in their regular practices. The cases are far from being } \\
\text { exhaustive - meaning: taken together, all cases do not fully explain the full theoretical variance of all } \\
\text { the subcategories and categories. But they are the most basic examples of how the participants report } \\
\text { to experience the principles at hand. } \\
\text { Please note: this is not what Philipp Mayring (2015) refers to as cases. In his terminology, a case is an } \\
\text { individual statement and each case originates from another participant. In the current study, a case is } \\
\text { an individual exemplification of the phenomenon whereas it is possible that several people mention the } \\
\text { same idea and thereby together form one single case with their statements. }\end{array}$ \\
\hline
\end{tabular}

The naming of the category labels has been done arbitrarily but they emerged by the requirement to denote the level of abstraction in the concepts. Whereas cases are real-life examples of the ideas at play, subcategories summarize several of them into broader concepts. They are then integrated into categories, which are more abstract tendencies of the former, which are themselves clustered together to big themes called topics. 


\section{Category Descriptions \& Coding Guidelines}

\section{CATEGORY}

LSSENCE

\section{ESSENCE}

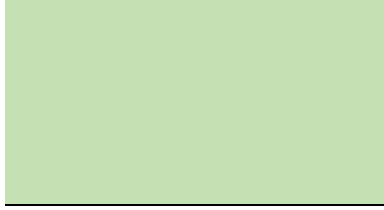

L2

\section{ACTIVITY}

L2

\section{STATE OF MIND}

\section{INSTRUMENT}

\section{DESCRIPTION / CODING RULE}

This category deals with the core of what worship is to the practitioner. It deals with the broad conceptualizations of the practice. As it turns out, worship can be conceived of as an activity, as a state of mind or an instrument.

Worship can be viewed as an activity. This means that it is something one does. It is a practice one actively engages in. Often, this occurs in the context of applied music and the utterance of praises and compliments to God.

As a basic essence, worship is not always only viewed as a practice (something one does) but as a state of mind, meaning that it is the mental participation in a given idea that glorifies God. Being in a state of mind which stands to the glory of God does not necessarily involve an active practice, although it can coincide with it.

Sometimes when believers reflect on the nature of what worship is supposed to be, it is conceived as an instrument to get closer to God. As such, it can be - and often it is - a means to an end, namely to become connected with the divine.

\section{ANCHOR EXAMPLES}

"For me, worship is an important means to communicate with God. Also, during the day and it is not just restricted to the time in church. It is something that accompanies me every day. It also works through songs or bible verses that come to mind."; "Music is more than just a tool in worship. It is an expression of divine creativity through us humans. And if it was a tool, then it was God's and not mine. He can inspire me to play music, for example. Worship is an expression. And experiencing God is a consequence of worship."

"I think it is difficult to draw the line between worship and communicating with God. You know, what is prayer and what is worship? Worship is a form of prayer ad exalting God with words. And I specifically do this with the help of music."; "Worship is both a state of mind as well as an activity.

When you cook: you can do this for Jesus. Everything you do you can do for God. This is worship. And as such, it is a state of mind but it is also every action that follows this mentality."

"For me, worship is a lifestyle. I believe that we constantly pray to something or are dedicated to something. And it is my goal to be focused on God as much as I can."; "You can get immersed in worship just like you can get immersed in sports. Or any other activity where you are creative."; "First, we have to define what we mean by worship. Theoretically, everything we do has to do with worship. For example, with my mother: when she is decorating her house with flowers, she considers this to be a form of worship. Traditionally, we regard musical aspects or the liturgical acts of 'making music together' as worship. And, indeed, this is a central aspect of my faith. But not only 'making music', also 'listening to it', for example. But music is an important aspect of worship. [...] It has a contemplative character but it goes beyond that."

"Worship is something that makes it easier for me to come to God. This is why I experience more of God in times of worship."; "Worship is a formidable instrument for caring about the relationship with an invisible person. I would describe worship and exaltation with the following analogy: it is like with good friends. What is a formidable instrument for caring about the relationship with friends? It is community. Specifically, it would be to eat together. Sitting at the same table and enjoying each other's company. So, worship is a formidable instrument to care about the relationship with 


\begin{tabular}{|c|c|c|}
\hline & & $\begin{array}{l}\text { God - with Jesus. And the adequate instrument here is music; songs. The } \\
\text { content of the communication with God in this case is the content of the } \\
\text { songs that are used for worshipping him." }\end{array}$ \\
\hline $\begin{array}{l}\text { L1 } \\
\text { MEANING }\end{array}$ & $\begin{array}{l}\text { Worship is not just something that happens without teleological } \\
\text { attachments. When believers engage in the practice, it holds a certain } \\
\text { personal meaning. What does it mean to the participants? This is the } \\
\text { question the subsequent categories want to shed light on. }\end{array}$ & $\begin{array}{l}\text { For me as a worship leader, it is a ministry I do unto other people who do } \\
\text { not sing with the microphone so that they can have an encounter with God. } \\
\text { I like to compare it with a rendez-vouz between a bride and a groom. They } \\
\text { come into a beautiful place and have a romantic tête-à-tête. As worship } \\
\text { leader I consider myself to be the person that makes this interaction as } \\
\text { smooth and romantic as possible. It's not always that sweet, of course. But } \\
\text { with the selection of the right songs where I myself give my best [...] I want } \\
\text { to see that it is as easy as possible for the audience to focus on Jesus. And if } \\
\text { I worship alone for myself, I am searching the presence of God - my groom } \\
\text { - and want to spend time with him and tell him how much I love him." }\end{array}$ \\
\hline $\begin{array}{l}\text { L2 } \\
\text { CONTENT }\end{array}$ & $\begin{array}{l}\text { When subjects are asked what worship means to them, often they explain } \\
\text { their intuitions in terms of certain contents. This content is what } \\
\text { constitutes the specific meaning of the practice. }\end{array}$ & $\begin{array}{l}\text { "For me, worship means to focus on God and to proclaim who he is. Also, } \\
\text { how I want to believe or understand things. Worship also consists of getting } \\
\text { a calmness when I am emotionally torn or upset. Then it means that I can } \\
\text { give it into the hands of God. But I think that it mainly consists of focusing } \\
\text { on God and who he is." }\end{array}$ \\
\hline $\begin{array}{l}\text { L3 } \\
\text { ENCOUNTERING } \\
\text { GOD }\end{array}$ & $\begin{array}{l}\text { A key constituent of the worship experience is the sensation to be in } \\
\text { contact with the divine. This is often framed in the terms of being in the } \\
\text { process of encountering God. }\end{array}$ & $\begin{array}{l}\text { "I mainly worship so that I can encounter God. Then I feel the presence of } \\
\text { God, it's like a normal part thereof. He is here; his presence implies that he } \\
\text { is here. However, it's not my primary goal to sense his presence to } \\
\text { experience his heart. To connect with him. I know that I am being } \\
\text { transformed in his presence. And it is a place that I need for my own } \\
\text { identity." }\end{array}$ \\
\hline $\begin{array}{l}\text { L3 } \\
\text { DISCOURSING } \\
\text { WITH GOD }\end{array}$ & $\begin{array}{l}\text { Standing in worship is first and foremost a method to converse and } \\
\text { discourse with God. On the one hand, it is to express praises but on the } \\
\text { other hand, it is also a means to become personal and pour out one's heart } \\
\text { to him. }\end{array}$ & $\begin{array}{l}\text { "In my life worship is an important means to communicate with God. Also } \\
\text { in everyday life. And this is not just restricted to a time during church where } \\
\text { people are doing this together. But it is something that accompanies me } \\
\text { every day. It occurs, amongst others, through songs or through bible verses } \\
\text { that come to one's mind. [...] These are songs that I remember in certain } \\
\text { times. And they are also moments of worship."; "The most important thing } \\
\text { I can say about worship is this: it's a relationship and dialogue with God } \\
\text { which changes everything." }\end{array}$ \\
\hline $\begin{array}{l}\text { L4 } \\
\text { EXALTING } \\
\text { PRAISING }\end{array}$ & $\begin{array}{l}\text { The classic idea of worship is to be lifting God higher and thereby giving } \\
\text { him praise. Exalting and praising him means showering him with } \\
\text { compliments. }\end{array}$ & $\begin{array}{l}\text { "In my view, God is absolutely worthy to be praised. In worship I can give } \\
\text { him back my time, thankfulness and honor."; "[... Worship means] } \\
\text { proclaiming who God is and to give him the glory that he deserves. } \\
\text { Likewise, and just as importantly, it means to focus on God and to submit } \\
\text { to him." }\end{array}$ \\
\hline L4 & $\begin{array}{l}\text { Apart from the classic process of complimenting God, the worship } \\
\text { process can also be accompanied by expressing one's gratitude for the }\end{array}$ & $\begin{array}{l}\text { "First and foremost, I practice worship in order to give God my thanks."; "It } \\
\text { is a way to express my gratitude and to honor him. For what he is and what }\end{array}$ \\
\hline
\end{tabular}


good things in life which are believed to be gifts from above. Likewise, in case the person experiences sorrows, one can also wail, cry, or express one's unhappiness. This is a tremendously intimate process where God is invited to listen to one's personal pleas.

\begin{tabular}{l}
\hline L4 \\
SHARING \\
INTIMATE \\
THOUGHTS \\
\hline L3 \\
GRASPING GOD'S \\
GREATNESS
\end{tabular}

This is a continuation from the previous case, where one's thanks or sorrows are expressed. Here, there is a personal dialogue taking place between the believer and what one believes to be responses from God.

The worship experience is not only a giving process but can also come along with the reception of intuitions. One is the impression of understanding the greatness

of

\section{L3 \\ SEEING \\ CREATIVITY

Seeing and understanding the divine greatness is one possible mechanism in the worship experience. Having the feeling of seeing his creativity all around us is a similar type of experience.

L3

SURRENDERING TO

GOD'S PRESENCE Having the sensation of perceiving God's presence can be a powerful
experience. Seeking after it explicitly and surrendering to this experience often delineates a key item of content in what worship means to the practitioner.

L2

When asking people what worship means to them, a pivotal response is what relevance it holds for their personal faith. Not surprisingly, the worship experts in the present research sample is unanimous in claiming that worship is central to their lives and their faith.

L3

The centrality of religiosity scale (CRS) is an official measure to figure

CENTRALITY

PRACTICE psychological constructs. A similar piece of information can be assessed when asked how important worship is deemed for their personal faith. To 'ordinary believers', worship holds a significant role, either as an activity, a state of mind or an instrument to approach God. To the worship experts in our sample, of course, worship takes up a central place for their beliefs and practices. he does. He is simply worthy to be worshipped. And as far as I am concerned, I can do this the best when I am using words and music.; "I worship so I can experience God's presence and can thank him. My character is such that I mainly do this so I can thank him. If I would be a more negative person, I could also use it as a way to wail and offer my sadness. That would also be a form of worship."

"The more spontaneous form of worship is the most honest one for me: here I tell God how I feel at the moment. I don't read a prayer because I utter it myself. I lead an active dialogue. In combination with the instrumental songs, this really hits deep for me."

"Because worship to me is realizing the greatness of God. This can take many forms. Sometimes I even had it in a context that was not Christian at all. Sometimes also in other denominations. Whenever we get a glimpse into the greatness of God, I think we are dealing with worship."

"This is when I stand in awe that God gives to these people. I would surely make the connection between God and human talents."; "I experienced the best worship times when we could be spontaneous. Where we started at one point and ended at another. Just when God's creativity can take the lead. Then you realize: now you are in the flow."

"Yes, when I experience God in worship is it a passive thing. I just let it flow over me. I don't do much. There I am almost still. I just let God to give his things to me I and I try to receive it. I absorb the music and also the lyrics. Then I just say: "God, there I am. Minister to me."'

"Worship has a high importance for me. I think I am worshipping and singing almost every day. Sometimes in formations where I have a worship band, or on a Monday evening for our worship soaking sessions, or on a Sunday during the service. But also, at home I am singing and worshipping a lot."

"Worship is extremely central and of tremendous relevance. For me, it is what gives me daily proof of that God exists. He wishes to receive my praise, but not that he would be dependent on it, but because he wants to get close to me. He wants to create a sense of awe in me. Yes, worship is truly essential. In times of worship, everything else is being put into the right relations and to the right focus."; "Worship is really central to me. I mean, we are talking about worship with music right now. If we were talking about worship in general it would be even more central. Because our lives are an expression of worship, how one lives the lifestyle, how one lives relationships with others. In all things we can worship God, meaning that we abide by his commandments and his wishes. Worship with music has a 


\begin{tabular}{|c|c|c|}
\hline & & $\begin{array}{l}\text { high relevance for me because it is a cool and easy medium to focus on } \\
\text { God." }\end{array}$ \\
\hline $\begin{array}{l}\text { L3 } \\
\text { EXERTING } \\
\text { CALLING }\end{array}$ & $\begin{array}{l}\text { Many participants hold that worship is our calling. This means that it is } \\
\text { not only what we are supposed to do as humans but that it is what we are } \\
\text { meant to do. We were made to worship. And by doing so, our states have } \\
\text { a tremendous significance because they stand in direct relation of why we } \\
\text { are here. }\end{array}$ & $\begin{array}{l}\text { "I also think that I am called to praise God with music. It is also something } \\
\text { that I have a compassion for. Music in general. And I believe that I can } \\
\text { worship God the best with things which he gave to me. I think that it is a } \\
\text { calling of mine to worship and praise God with the help of music." }\end{array}$ \\
\hline $\begin{array}{l}\text { L3 } \\
\text { IDENTITY } \\
\text { FORMATION }\end{array}$ & $\begin{array}{l}\text { Worship is not only relevant due to the fact that "this is what we are made } \\
\text { for" but it only plays a role in becoming who we are destined to become. } \\
\text { If by worshipping we are believed to connect to our maker, we thereby } \\
\text { also form our identities by seeking after God in worship. }\end{array}$ & $\begin{array}{l}\text { "I know that I am being changed in the presence of God. And this is a place } \\
\text { where I know that I need it over and over again for my own identity. It } \\
\text { reinforces my identity: hey ok, you love me, you are for me, you are here. } \\
{[\ldots] \text { Yes, I would say that worship is forming my identity." }}\end{array}$ \\
\hline $\begin{array}{l}\text { L4 } \\
\text { BELIEF } \\
\text { FORMATION }\end{array}$ & $\begin{array}{l}\text { The Bible tells us that faith comes from hearing a sermon and the word of } \\
\text { God (Romans 10:17). Moreover, some subjects say that by uttering the } \\
\text { words of the worship songs out loud with an honest engagement, their } \\
\text { faith grows and their beliefs form. }\end{array}$ & $\begin{array}{l}\text { "To me, worship is not just musical but it is all that is giving God the glory. } \\
\text { It means thankfulness for all that is, for what I am given, what I experience, } \\
\text { and what I see. [...] It means to articulate who God is. Worship is a state of } \\
\text { mind where I may be fully aware that God exists. That he is in full control. } \\
\text { It is a hope that I may live. A hope that God is here. I think that worship } \\
\text { strengthens these beliefs." }\end{array}$ \\
\hline $\begin{array}{l}\text { L3 } \\
\text { MOTIVATION }\end{array}$ & $\begin{array}{l}\text { Why exactly do believers set out to engage in worship practices? This is } \\
\text { the question the subsequent subcategories intend to address. }\end{array}$ & $\begin{array}{l}\text { "In my view, the goal of worship is to be directed and focused on God and } \\
\text { to give him the glory."; "I think there are several reasons why we worship. } \\
\text { On the one hand, I certainly worship in order to feel his presence. On the } \\
\text { other hand, I also think that we do it to honor him. I believe that he deserves } \\
\text { our exaltation." }\end{array}$ \\
\hline $\begin{array}{l}\text { L4 } \\
\text { FINDING PEACE IN } \\
\text { GOD }\end{array}$ & $\begin{array}{l}\text { When deliberately participating in the worship practice, the hopes of } \\
\text { finding peace with God play out as one non-negligible motivator. }\end{array}$ & $\begin{array}{l}\text { "Yeah, this is one consequence of worship. It's possible that when you're } \\
\text { experiencing God, that your getting calm and experiencing a deep peace. } \\
\text { [...] Sometimes I sense an inner peace in such situations." }\end{array}$ \\
\hline $\begin{array}{l}\text { L4 } \\
\text { SEEKING } \\
\text { RELATIONSHIP } \\
\text { WITH GOD } \\
\end{array}$ & $\begin{array}{l}\text { Underlying most worship endeavors lies the intention to connect and } \\
\text { cultivate a relationship with the divine. By using the practice as a means, } \\
\text { it is aspired to effectively manage to get into a communal atmosphere with } \\
\text { him. }\end{array}$ & $\begin{array}{l}\text { "Indeed, worship helps me to spend quality time with God. It isn't } \\
\text { something I have to do or to create. But it is a quality time akin to when } \\
\text { you're going to eat with your friends. Lin this sense, worship to me is quality } \\
\text { time with God." }\end{array}$ \\
\hline $\begin{array}{l}\text { L4 } \\
\text { SELF-EXPRESSION } \\
\text { BEFORE GOD }\end{array}$ & $\begin{array}{l}\text { Frequently, the practice is described as a creative act. It is therefore a } \\
\text { method to achieve some sort of self-expression but not only for one's own } \\
\text { good but also to please God. One's self-expression then becomes the } \\
\text { vessel to praise and worship God. }\end{array}$ & $\begin{array}{l}\text { "Worship can mean to say who God is for me. But it can also mean that I } \\
\text { use my gifts for him. [...] It can also consist of drawing and painting. It is } \\
\text { mainly to use the gifts that we have. And therein to give God the glory." }\end{array}$ \\
\hline $\begin{array}{l}\text { L4 } \\
\text { REMEMBERING } \\
\text { GOD }\end{array}$ & $\begin{array}{l}\text { One possible motivation to enter the practice is to remember who God is } \\
\text { and what he has done both in the world as well as in one's life. It comes } \\
\text { along with a meditative function. }\end{array}$ & $\begin{array}{l}\text { "Yes, of course, on aspect of why I worship is to sense his presence. But } \\
\text { another one is to constantly remember how great he is. He is bigger than my } \\
\text { sorrows. And I also worship in order to remind myself what he already did } \\
\text { in my life. All the many good things and all the gifts and people he gave to } \\
\text { me. To remind myself that he looks out for me." }\end{array}$ \\
\hline
\end{tabular}




\begin{tabular}{|c|c|c|}
\hline $\begin{array}{l}\text { L4 } \\
\text { EXALTING } \\
\text { PRAISING }\end{array}$ & $\begin{array}{l}\text { As above in the 'content', worship as a means to deliver compliments to } \\
\text { God is also a key motivation to enter the practice. }\end{array}$ & $\begin{array}{l}\text { "In my own life, worship holds the function to praise God in the atmosphere } \\
\text { in which I am experiencing him. Very often, it is not really dependent on } \\
\text { singing if I am experiencing him. Usually, I just worship him because he } \\
\text { deserves it." }\end{array}$ \\
\hline $\begin{array}{l}\text { L4 } \\
\text { SHOWING } \\
\text { OBEDIENCE } \\
\text { GOD }\end{array}$ & $\begin{array}{l}\text { Since it is often believed that worship is a central constituent of human } \\
\text { essence, it is a form of obedience to engage in the worship experience. } \\
\text { God wants us to honor him and by doing so, we are professing to be good } \\
\text { believers who are obedient to his wishes. }\end{array}$ & $\begin{array}{l}\text { "Emotionally, I don't always experience God during times of worship. But } \\
\text { then sometimes it is simply a decision to set out and worship him. And when } \\
\text { I sing along and get into the flow, the it can make a huge difference if I just } \\
\text { sing a little or whether I really immerse in it. But I think: emotionally we } \\
\text { don't always have to experience him. Sometimes it's just a decision and then } \\
\text { we praise God. This is ok. Then it has more to do with awareness." }\end{array}$ \\
\hline $\begin{array}{l}\text { L4 } \\
\text { GOD DESERVES } \\
\text { THE HONOR }\end{array}$ & $\begin{array}{l}\text { The question "why do you worship?" is frequently answered with } \\
\text { "because he deserves it". As God, exaltation and worship to glory is } \\
\text { something deserves. To many believers, it thus seems almost } \\
\text { consequential - a logical act - to step into the shoes of a worshipper. }\end{array}$ & $\begin{array}{l}\text { "Sometimes I simply worship God because he deserves it. To say who he is. } \\
\text { And also, that I know who he is. But it's not about my emotions; it's about } \\
\text { that I surrender to him and God can dedicate me." }\end{array}$ \\
\hline $\begin{array}{l}\text { L4 } \\
\text { LETTING GOD } \\
\text { TAKE CONTROL }\end{array}$ & $\begin{array}{l}\text { Especially in charismatic denominations, it appears that the wish to } \\
\text { surrender one's life and the moment to God is a key motivation to enter } \\
\text { the worship process. }\end{array}$ & $\begin{array}{l}\text { "It's a little bit like going into a trance with the instrument. You don't think } \\
\text { so much: I do this and then this happens. I just let go."; "The attitude is } \\
\text { certainly important. But eventually you just have to be able to let go [and } \\
\text { give control to God]."; "It's not about my feelings. It's about giving myself } \\
\text { to God and he can affirm me." }\end{array}$ \\
\hline $\begin{array}{l}\text { L1 } \\
\text { MUSIC }\end{array}$ & $\begin{array}{l}\text { The worship experience is often accompanied with music. The practice is } \\
\text { greatly facilitated through the help of melodies and texts, sung either in } \\
\text { community or alone. }\end{array}$ & $\begin{array}{l}\text { "I think music can support much [in worship]. And that's mostly in the } \\
\text { context where you are consciously worshipping and hence have major } \\
\text { experiences with God. Because this is where you actively set the focus on } \\
\text { God." }\end{array}$ \\
\hline $\begin{array}{l}\text { L2 } \\
\text { MELODY }\end{array}$ & $\begin{array}{l}\text { The melodic tunes strongly define the worship ceremonies. They can form } \\
\text { an atmosphere and hence lead the thoughts and emotions of the } \\
\text { worshipper in a given direction. }\end{array}$ & $\begin{array}{l}\text { "I think the songs that resonate with my situation are helpful to worship. Or } \\
\text { when I like the melody. Or when it's my style."; "When there are words, I } \\
\text { can grasp the experience with my mind. But to be honest, it's enough for me } \\
\text { to only have the musical aspects. But then it's really dependent on how the } \\
\text { instrument is played." }\end{array}$ \\
\hline $\begin{array}{l}\text { L3 } \\
\text { STYLE }\end{array}$ & $\begin{array}{l}\text { Just as there are many different musical styles in "regular" or 'secular' } \\
\text { music, there are just as many styles when it comes to worship. Over time, } \\
\text { all possible styles in the music industry have been adopted to appropriate } \\
\text { a worship context. }\end{array}$ & $\begin{array}{l}\text { "I am more drawn to spherical music [laughes]. But as for the other [styles], } \\
\text { I am getting to know them better and better. But maybe it has something to } \\
\text { do with character. I think people who are more celebrating persons have a } \\
\text { better access to God this way. But I am more the type who likes calm and } \\
\text { spherical music." }\end{array}$ \\
\hline $\begin{array}{l}\text { L4 } \\
\text { SPIRITUAL } \\
\text { WAVELENGTH }\end{array}$ & $\begin{array}{l}\text { One participant has highlighted that the music style of a song can has a } \\
\text { certain intuitive or affective ring to it. This is perceived as a wavelength } \\
\text { (metaphorically speaking) which is inherently spiritual and governs the } \\
\text { worship experience in a given emotional way. }\end{array}$ & $\begin{array}{l}\text { "Yes, the style surely has a significant influence. But the style preferences } \\
\text { are quite subjective and which can act as a platform for me [to engage with } \\
\text { God in worship]. Jazz does not create a platform for me to connect with } \\
\text { God. But spherical music does and also music with a similar mindset or }\end{array}$ \\
\hline
\end{tabular}




\begin{tabular}{|c|c|c|}
\hline & & $\begin{array}{l}\text { spiritual wavelength like me can act for me as a platform where I can ascend } \\
\text { and come to God." }\end{array}$ \\
\hline $\begin{array}{l}\text { L4 } \\
\text { CONCEPTS }\end{array}$ & $\begin{array}{l}\text { The musical style is sometimes associated with some cognitive concepts. } \\
\text { One example would be to have pompous orchestra sounds which elicit the } \\
\text { notion of a "majestic" atmosphere. In order to provoke such a feeling of } \\
\text { God's majesty, these kinds of sounds can be employed. These mental } \\
\text { concepts govern a worshipper's thoughts to the idea of, for example, the } \\
\text { grandness of the majestic God. }\end{array}$ & $\begin{array}{l}\text { "Yes, worship definitely helps me to feel the presence of God. To me it is } \\
\text { one medium of many. And what helps me a lot is that I like 'grand' music. } \\
\text { Big, dramatic music. [...] The beauty of the music helps me a lot in this. But } \\
\text { also the singing in a group is helpful."; "Of course, it is a question of style. } \\
\text { The musical style. I don't know if it is biological or so. But songs that come } \\
\text { with a huge presence in volume; that's what resonates with me. [...] A song } \\
\text { that is very thick makes you feel like you're in a stadium amidst a hundred } \\
\text { thousand people. For me, that's an image of God's generosity and his love. } \\
\text { It manifests itself. As such, songs that are voluminous or are majestic - like } \\
\text { some hymns - they really touch me. They feel very mighty. These are styles } \\
\text { that touch me more, emotionally and spiritually, than other songs. But that's } \\
\text { a matter of style and they have to do with concepts in music: mighty, } \\
\text { triumphal, or big. I associate them with spiritual images of God. And if it } \\
\text { does not have these images in a worship song, then it holds less of an } \\
\text { influence over me." }\end{array}$ \\
\hline $\begin{array}{l}\text { L4 } \\
\text { PERSONAL } \\
\text { PREFERENCE }\end{array}$ & $\begin{array}{l}\text { Naturally, the way a person reacts to any given song to the most part is } \\
\text { due to personal preferences. There can be music styles that are inherently } \\
\text { liked and others that are disliked based on the conditioning of a person. } \\
\text { The more a worship song resonates with a person's taste, the more it helps } \\
\text { the believer to get into a worship mood and to have more effective 'divine' } \\
\text { worship experiences. }\end{array}$ & $\begin{array}{l}\text { "There are also songs that I don't like so much in terms of their melodies. } \\
\text { But that's simply a matter of taste. Then it just speaks to me less. In these } \\
\text { cases, I would find it difficult [to dive into the worship]. But there are also } \\
\text { songs where it works better."; "The style of the worship song is relevant } \\
\text { inasmuch as that there are styles that I really don't like." }\end{array}$ \\
\hline $\begin{array}{l}\text { L4 } \\
\text { PROPHETIC }\end{array}$ & $\begin{array}{l}\text { There are some denominational streams that implement a musical style } \\
\text { which is sometimes referred to as "prophetic". It is a spontaneous form of } \\
\text { music where the instrumentalists, the lead singers and the congregation } \\
\text { effectively create a song on the spot together in a non-directed way. } \\
\text { People raise their voices in singing and the instrumentalists play along. } \\
\text { Everything happens without a script and the goal is to allow for maximal } \\
\text { freedom for everyone to express their creativity to the glory of God. }\end{array}$ & $\begin{array}{l}\text { "When I worship God with music, it has something very tender about it. } \\
\text { Something that comes from the heart; almost something magical. [...] It has } \\
\text { something to do with prophecy. You can play an instrument and accompany } \\
\text { a worship song. But you can also play an instrument prophetically and this } \\
\text { can influence the musical worship." }\end{array}$ \\
\hline $\begin{array}{l}\text { L3 } \\
\text { MEANING }\end{array}$ & $\begin{array}{l}\text { The melody itself can have certain consequences and be attributed with } \\
\text { meaning when applied in the context of a worship experience. }\end{array}$ & $\begin{array}{l}\text { "Music is a tool and it helps us to lay other things to the side and so that we } \\
\text { can dive into the music. It hence helps us to set the focus on God." }\end{array}$ \\
\hline $\begin{array}{l}\text { L4 } \\
\text { CHALLENGE } \\
\text { PEDESTAL }\end{array}$ & $\begin{array}{l}\text { A song always occurs with a melody which corresponds with a subject's } \\
\text { predisposition or runs counter to it. Depending on which of the two is the } \\
\text { case, the music style can make it challenging to enter an open worship } \\
\text { experience (which is often conceived of as an encounter with God) or it } \\
\text { can make it easy to engage in this state of mind. The first would mean that } \\
\text { the style reflects a challenge for the experience and the second implies } \\
\text { that it is a pedestal for the same. }\end{array}$ & $\begin{array}{l}\text { "I believe that music styles can help us to pick us up. But it's not dependent } \\
\text { on it. It may be that a full band is here and plays everything perfectly. And } \\
\text { still there is no breakthrough into his [God's] presence. And another time } \\
\text { there is perhaps only someone with a piano on the stage and it is amazing } \\
\text { from the very first second."; "It's the same with the harmonies: it makes a } \\
\text { difference if you're playing something mundane or something sophisticated. }\end{array}$ \\
\hline
\end{tabular}




\begin{tabular}{|c|c|c|}
\hline & & $\begin{array}{l}\text { And when it's really simple, it can become boring. Then I lose interest and } \\
\text { it gets arduous." }\end{array}$ \\
\hline $\begin{array}{l}\text { L4 } \\
\text { INDEPENDENT }\end{array}$ & $\begin{array}{l}\text { In rare cases, the worship experience may be said to be unaffected by the } \\
\text { musical style applied in the ceremony. This would be a situation where } \\
\text { the practice is independent from the music. }\end{array}$ & $\begin{array}{l}\text { "With instrumental worship music, I can have a deeper encounter with God } \\
\text { because I am not influenced by a certain music, text, word [or melody]." }\end{array}$ \\
\hline $\begin{array}{l}\text { L4 } \\
\text { INTIMATE/ } \\
\text { POWERFUL }\end{array}$ & $\begin{array}{l}\text { To musicians, creating musical art is a craft. They can direct emotions and } \\
\text { implicate atmospheres. Especially when in worship, it is often aspired to } \\
\text { create music that is revering and feels intimate or powerful. This helps the } \\
\text { practitioner to open up and feel intimate before God or to have a powerful } \\
\text { experience where one assumes to sense his power. }\end{array}$ & $\begin{array}{l}\text { "As a musician I have a strong affinity to wordless worship music. For me, } \\
\text { it is equally justified and powerful- or, it is just as formidable an instrument } \\
\text { - as worship with music and text. [...] But sometimes it also leads me to a } \\
\text { deeper encounter with God because there is no suggestion coming from } \\
\text { outside. [...] With instrumental worship music, I can have a much more } \\
\text { intimate experience with God because I am not influenced by a sentence or } \\
\text { a word." }\end{array}$ \\
\hline $\begin{array}{l}\text { L4 } \\
\text { EMOTIONAL } \\
\text { CARRIER }\end{array}$ & $\begin{array}{l}\text { This is perhaps one of the most intuitively understandable categories in } \\
\text { this domain. Music is a highly effective transporter and carrier of } \\
\text { emotions. By skillfully implementing it, music can set a desired emotional } \\
\text { focus and elicit a spiritual response in the listener. }\end{array}$ & $\begin{array}{l}\text { "And when the worship song is only instrumental, it is much easier for me } \\
\text { to bring my emotional states to God."; "It happens on the sound level. } \\
\text { Sometimes it is the words but more often it is the sound that resonates with } \\
\text { me and gets close to me and is beautiful." }\end{array}$ \\
\hline $\begin{array}{l}\text { L2 } \\
\text { TEXT }\end{array}$ & $\begin{array}{l}\text { Music can occur with and without lyrics. This is no different in worship. } \\
\text { However, the practice often comes along with text because the lyrics } \\
\text { transport an intellectual value. God is usually praised not just with } \\
\text { melodic tones but with text. }\end{array}$ & $\begin{array}{l}\text { "I strongly react to words. Good and true biblical texts which really have } \\
\text { Jesus at the center. I experience this focus as truly helpful. But it is also } \\
\text { possible that, when I hear a song where I do not agree with the lyrics, it can } \\
\text { be quite a stumbling block."; "I have issues with worship songs with where } \\
\text { I have no connections to the texts. This could be a very old song. Or a song } \\
\text { with which I disagree theologically. But it depends on the song. And mostly } \\
\text { on the text." }\end{array}$ \\
\hline $\begin{array}{l}\text { L3 } \\
\text { PREDETERMINED } \\
\text { L4 } \\
\text { DIRECTION }\end{array}$ & $\begin{array}{l}\text { For the most part, the lyrics are a given. They stem from songs that have } \\
\text { been written beforehand and can be read from a booklet, a projector or a } \\
\text { screen. If the text is already there, then there is one quintessential } \\
\text { consequence: it guides the locus of attention (or the intellectual focus) in } \\
\text { a specific predetermined direction. }\end{array}$ & $\begin{array}{l}\text { "On the one hand we have the lyrics: actually, I never experience a great } \\
\text { time with God when the song, for example, highlights my own needs. I think } \\
\text { songs where we submit to God are superb and in the right time, we definitely } \\
\text { need them. But that's not really worship for me. Bringing your needs to God } \\
\text { is surely justified. [...] But there are also songs which are proclamatory, } \\
\text { directed to the greatness of God and to what he does. Then I fly like an eagle. } \\
\text { Then I quickly start to proclaim and sing along as well. And as such the text } \\
\text { is really important for me." }\end{array}$ \\
\hline $\begin{array}{l}\text { L3 } \\
\text { SPONTANEOUS }\end{array}$ & $\begin{array}{l}\text { The reverse would be true if the melody is played and the people are } \\
\text { invited to conjure up their own words to praise God. This does not usually } \\
\text { happen throughout the whole worship ceremony but in demarcated } \\
\text { musical phases where the tones are generic and the lyrics are faded out. }\end{array}$ & $\begin{array}{l}\text { "Existing songs don't really touch me strongly. [...] And very often these } \\
\text { are the spontaneous moments, where waves or an atmosphere come in. } \\
\text { There you really feel how the room gets thick. It happens when people praise } \\
\text { God with their own words spontaneously. And not with pre-printed } \\
\text { statements that they have almost memorized. Because now for each word } \\
\text { they decide for themselves which they want to use and the utter them the } \\
\text { way they want. It is much mor honest and serious that way." }\end{array}$ \\
\hline
\end{tabular}




\section{L4}

PRAYERFUL,

PROPHETIC,

REPETITIVE occur alone or all together at once.

The text can be prayerful, meaning that it is an individual dialogue between the believer and God implemented in the musical experience.

It can be prophetic, or, topical, which refers to the idea that there are specific prayerful topics that are provided by the worship band and the congregation can feel free to participate in the topic using their own words.

Frequently, the atmosphere becomes meditative. This environment is deliberately governed as such by employing repetitive textual elements.

L2

\section{EXECUTION}

This category hosts the three variants how a worship song can be physically effected: only instrumental, instrumentals \& text, only sung text.

\section{L3}

\section{ONLY}

INSTRUMENTAL

As seen above, it is entirely possible to enter into the worship practice without any text. Then the musical tunes are used to generate an atmosphere of gratitude, intimacy or praise and this then constitutes the worship practice.

\section{L3 INSTRUMENTALS \&}

TEXT

L3

ONLY SUNG TEXT

L2

MEDIUM

L3

FOCUS ON GOD

L4

CREATES

PLATFORM
In the vast majority of all cases, the worship song is implemented with both instrumentals and text. This way, the two facets may complement each other.

In rather rare instances, the song can be a cappella. It has vocal sound and lyrics but there are no instrumentals.

Music plays a certain role in the initiation and continuation of worship experiences. These aspects are clustered under the category "medium" because music mediates these functions in the worship process.

One important role music has in the whole scheme is to help the practitioner focusing on God. It directs one's attention away from oneself and on to something else. In this case, to the divine.

Music has the unique capability to set the mood of the individual and

A hence it can "create a platform" where the thoughts revolve around the divine.
“... here I tell God how I feel at the moment. I don't read a verse out loud but I formulate it myself. I lead an active dialogue. This is the deepest form of worship for me, together with the instrumental songs."; "In the spontaneous area, I see three subcategories: there is the spontaneous worship that you do just for yourself. And then there are two subsequent ones for leading the worship. The one is that you do it together with the audience and you deliberately give them phrases that you can repeat. The people copy that and it becomes big. And the third form which I have seen: in worship there can be a moment where they say something spontaneously, but there is not the atmosphere where everybody wants to repeat it. Instead, everybody is peacefully quiet and everyone is lurking. It seems to me like this is a form of prophetic prayer where God speaks into the life of people. A person speaks up and it almost feels like a sermon."

"For me, there are three categories of worship: not only instrumental and words. In my view: there can be instrumentals, words and spontaneous words. These forms are all very different from one another and then I also see three subcategories."

"And when it's only instrumental, it is easier for me to bring my emotional states to God."; "When I hear instrumental and it evokes emotions in me which I associate with past experiences where they were similar to now, them I immediately feel drawn back into the very same atmosphere. The instrumental worship songs with which I engage are generally ones that lower the pace and bring peace."

"Music without words can be awesome when you are in a moment where you are led by the Holy Spirit to express your thankfulness and praise. But words help to declare who he is. These things have to be uttered out loud." This is a category that logically follows from indications many participants hint at when the category 'only instrumental' is coded.

"Uhm, yes, I think music in worship helps to sense the presence of God. But it probably helps me less than it can actually disturb me. When you are a musician yourself, then you can get bothered more by bad music than it can help you to get into the aspired mood. But - well - it still helps."

"[In worship] there is a shift of my focus. That's always the case. I look away from myself unto God who is so much bigger than my problems. It is a positive effect, an experience that takes away some weight and frees me. I have this regardless if other people are around or whether I'm alone."

"Certain music creates more of a platform in which I can experience God than other music does."; "I would say that I experience God with worship 


\begin{tabular}{|c|c|c|}
\hline & & $\begin{array}{l}\text { songs which really speak into my situation. Where you feel: this is where I } \\
\text { stand or where you feel that it builds you up in your relationship with God." }\end{array}$ \\
\hline $\begin{array}{l}\text { L4 } \\
\text { CREATES NEW } \\
\text { PERSPECTIVES }\end{array}$ & $\begin{array}{l}\text { Sometimes, a person can be absorbed by the ticking of one's own } \\
\text { thoughts. Perhaps one is ruminating about the day or about present } \\
\text { problems and it becomes difficult to exit this mood in order to focus on } \\
\text { God. Music can aid in this process because the evoked emotions create } \\
\text { new perspectives. One sees things in a different light and this helps to be } \\
\text { open for God. }\end{array}$ & $\begin{array}{l}\text { "What I find really interesting is that worship distracts me from my own } \\
\text { thoughts. It brings us to a new dimension. There is a new perspective. And } \\
\text { I find this really fascinating because very often I bob up and down in my } \\
\text { own things. And when I engage in worship, I leave my own little circle and } \\
\text { the whole thing becomes a lot bigger. I am being redirected away from } \\
\text { myself. I can put the things that bother me to my side a lot easier." }\end{array}$ \\
\hline $\begin{array}{l}\text { L4 } \\
\text { MENTAL } \\
\text { ACTIVATION }\end{array}$ & $\begin{array}{l}\text { All in all, music activates cognitive and emotional processes. This fact } \\
\text { can be used to facilitate the worship experience in focusing on God. }\end{array}$ & $\begin{array}{l}\text { "Worship music helps me to stay concentrated. Yes, maybe it is an amplifier } \\
\text { of what that which I do myself. I have asked this myself already: why is it } \\
\text { so much easier for me when I play music? I am not so sure why but I only } \\
\text { know that it works. Pretty much always." }\end{array}$ \\
\hline $\begin{array}{l}\text { L3 } \\
\text { PROVIDES } \\
\text { FREEDOM }\end{array}$ & $\begin{array}{l}\text { As the name of the subcategory already infers, music can mediate a } \\
\text { sensation of peace. It can also help to let the subject feel free so that one } \\
\text { can be disinhibited in the approach to God in worship. }\end{array}$ & $\begin{array}{l}\text { "The instrumental worship songs that I hear are ones that provide calmness } \\
\text { and freedom; they deescalate me. Those are not metal-songs. They are } \\
\text { soulful, emotional things. They bring me peace and bring me to a place } \\
\text { where I can hear God. There I stop my thoughts and listen. This I can } \\
\text { experience there. Then the dialogue comes." }\end{array}$ \\
\hline $\begin{array}{l}\text { L3 } \\
\text { TRANSPORTS } \\
\text { EMOTIONS }\end{array}$ & $\begin{array}{l}\text { This is perhaps the most intuitive idea for the whole topic: music is } \\
\text { designed to transport emotions. If poetry is the language of the mind, then } \\
\text { music is the language of the heart. It helps to evoke specific emotions. }\end{array}$ & $\begin{array}{l}\text { "Music in worship holds several functions. On the one hand, it creates an } \\
\text { atmosphere, a feeling. It transports emotions. I like that a lot. Music has the } \\
\text { advantage that it directly goes into the heart without the detour via the } \\
\text { mind." }\end{array}$ \\
\hline $\begin{array}{l}\text { L4 } \\
\text { ATMOSPHERE }\end{array}$ & $\begin{array}{l}\text { In the worship ceremony, this fact is used deliberately to create and } \\
\text { transport an atmosphere. Often, this atmosphere is supposed to carry a } \\
\text { sacred ring to it as to facilitate the worship experience. }\end{array}$ & $\begin{array}{l}\text { "Yes, I believe that music really sets this atmosphere free. On the one hand, } \\
\text { music can strongly influence the emotions. But on the other hands also the } \\
\text { text and then one become aware about what it's really about. And the spirit, } \\
\text { if he is glorified, is strongly present." }\end{array}$ \\
\hline $\begin{array}{l}\text { L4 } \\
\text { CORRESPONDENCE } \\
\text { WITH } \\
\text { PSYCHOLOGICAL } \\
\text { STATE }\end{array}$ & $\begin{array}{l}\text { Music can coincide or run counter to a person's psychological state. If the } \\
\text { emotions on the musical agenda correspond to the mental states a subject } \\
\text { is already in, then it is felt as something natural and pleasant. It may aid } \\
\text { the individual in opening up and engaging with the worship ceremony. If } \\
\text { the opposite is the case, it does not make things easier. }\end{array}$ & $\begin{array}{l}\text { "Not all worship songs have the same effects on me. There are songs where } \\
\text { I think that the song that has been written does not resonate at all with my } \\
\text { current situation. And then I have difficulty to identify with the song."; "It } \\
\text { really depends on how I feel in the moment and if it corresponds to my } \\
\text { personal situation or the situation of the church. There is not "the' song that } \\
\text { always induces an experience with God."; "Sometimes a worship song does } \\
\text { not do anything for me. Then a month later, because the context has } \\
\text { changed, it can have a positive effect on me." }\end{array}$ \\
\hline $\begin{array}{l}\text { L4 } \\
\text { CORRESPONDENCE } \\
\text { WITH } \\
\text { MEMORIES }\end{array}$ & $\begin{array}{l}\text { Songs can remember us about events and mental states in the past. } \\
\text { Sometimes it only requires a song which has been played at a given } \\
\text { moment in the past and the memories come back. If the memories are } \\
\text { pleasant or - even better - if they are associated with an experience with } \\
\text { God, this experience can be re-triggered merely by playing the music. }\end{array}$ & $\begin{array}{l}\text { "These can be songs that have already spoken to me intensely or that have } \\
\text { come up in situations where I have experienced God before when the song } \\
\text { was playing. Where God has spoken to me or where something has become } \\
\text { clear to me as the song was on. It then acts like a door. With this I find the } \\
\text { way to his presence. Because I have already experienced God with these } \\
\text { songs. It can be like this or they can be songs that deal with something that }\end{array}$ \\
\hline
\end{tabular}


I ruminate about at the moment."; "Such [impactful] songs are the ones which I have heard over and over again in a certain phase where I have experienced God specifically. And when I listen to them again - even after 15 years - the music can be horrible, but I can get in and - boom - it just comes over me. Perhaps because there is a certain conditioning here."

L4

SELF-EXPRESSION

L3

QUALITY OF MUSIC

The quality if the music is not to be underestimated. It can greatly define can be a form of self-expression with the goal to honor God. Music can hence in this context be a medium for expressing oneself creatively.

the direction of the worship experience.

L4

FACILITATING

If the music is liked by the participant, then it can come along with positive associations which in turn help the person to focus on God and to engage in worship. In the best case, it can even aid the person to have a divine experience with God in the worship context.

The opposite is true for when the music does not fare well with the listener. If the quality is not good, it is experienced as a tremendous distraction up to the point that it is difficult to remain in the audience. Bad music is hindering the whole situation.

\section{L2}

STRUCTURE

L3

GIVEN

L3

FREE

The music itself always has a given structural set up. This can also have an impact on how the worship endeavor is perceived.

"Given songs" are the ones that we usually think of when reflecting upon the structure of music. These are songs that have been pre-written and orchestrated to lead the audience in a specific direction.

The reverse is when a song is free, meaning that it does not have a clear structure. There, the audience has the liberty to sing what they wan
"As a musician, I would say that it also depends on the style. I don't want to make myself dependent on it, but there are styles where I realize that I have to decide to get into the mood. But there are also others where I can express myself better, and there it is easier for me because I like it better." "When it's only instrumental, then the quality of how they play has a huge influence on me."; "When you're a musician yourself, then bad music can really hinder you instead of helping you [to get into the presence of God in worship]."

"I think generally, good music helps to have an experience with God. Just in general. I already had such experiences with God in concerts that had nothing to do with traditional worship music. There I sit in a stadium and suddenly I sense the presence of God. I believe that there is something divine in music."

"... when the quality of the music is bad, then it hurts me so much that it becomes difficult for me to focus on God. And to let myself go. It becomes almost impossible for me."; "Ill performed music invokes negative emotions in me. It's like feeling awkward for others. I then often tell myself: 'What do the other people think?' It's like I shiver, and it hurts [laughes]. And this makes it really difficult."

"No, I shouldn't say that there is less of God in structures worship [laughes]. But there I experience less of God. Structure [in music] can help but it can also limit me a lot." because the instrumentals only provide minimalistic background music. This is supposed to render an intimate ambient where people can come to God and be their selves.
"In 'normal worship', sometimes it is more difficult for me because you aren't as free. The songs are given [by the worship leaders]. There it is simply a deliberate form of worship where the words that we utter become the praise and worship. The words become a proclamation. This is more of a conscious decision whereas the other [free worship] is a liberation."

"I have experienced the best worship times when you can be spontaneous and like this' but it just works."; "Existing or given songs don't really touch me as much. And as someone who produces songs myself, that's a significant discovery. [...] And often it is the spontaneous moments where waves or an atmosphere are coming. There you feel how the room gets thick and free. [...] It's not about pondering about it "now I have to do it like this 


\begin{tabular}{|c|c|c|}
\hline & & $\begin{array}{l}\text { [of God's presence]. This is the moment where people start to worship God } \\
\text { with their own words." }\end{array}$ \\
\hline $\begin{array}{l}\text { L1 } \\
\text { METHOD }\end{array}$ & $\begin{array}{l}\text { There are several ways, or methods, how worship can be approached. } \\
\text { These notions are clustered under the heading method. }\end{array}$ & $\begin{array}{l}\text { "I believe that musical worship is a part of our creative being. It's about } \\
\text { creating something. Worship can hence be many things at once: all artistic } \\
\text { things - and art is not just restricted to dancing or painting, it is extremely } \\
\text { broad. Here it's about our creative essence. By making music as a creative } \\
\text { act we are making a step towards God." }\end{array}$ \\
\hline $\begin{array}{l}\text { L2 } \\
\text { WORSHIP MODES }\end{array}$ & $\begin{array}{l}\text { On the one hand, worship can be practiced in a communal effort or alone. } \\
\text { And on the other hand, it can be practiced in different postures. }\end{array}$ & $\begin{array}{l}\text { "When I am worshipping alone, I don't have very strong experiences with } \\
\text { God. It' really hard for me to be by myself and worship. [...] And for me } \\
\text { it's really true: when I am together with a group of people or when I am } \\
\text { standing in a church service in worship - and the most when I am leading } \\
\text { worship on the stage - the I experience God the most." }\end{array}$ \\
\hline $\begin{array}{l}\text { L3 } \\
\text { ALONE }\end{array}$ & $\begin{array}{l}\text { Hen engaging in worship, this is not always in an official church meeting. } \\
\text { Believers often worship for themselves at home or outside in nature, not } \\
\text { rarely with the help of their own instruments or with the help of digital } \\
\text { music from CDs, YouTube, Spotify or the like. They can do so alone } \\
\text { which is sometimes easier for the subjects because they do not feel } \\
\text { distracted by other people. }\end{array}$ & $\begin{array}{l}\text { "I realize: when I worship for me alone by myself, then I pretty much always } \\
\text { experience him emotionally or physically."; "For me there are two } \\
\text { scenarios: one is the worship by myself and the other is the worship with the } \\
\text { band or with the church, which also includes the coordination with the band } \\
\text { and leading the room."; "Also at home by myself I am often worshipping } \\
\text { and singing." }\end{array}$ \\
\hline $\begin{array}{l}\text { L4 } \\
\text { PLAYBACK }\end{array}$ & $\begin{array}{l}\text { There are many digital mediums a person can use to worship alone. There } \\
\text { are single songs, albums and whole playlists on Spotify and other } \\
\text { platforms which are deliberately constructed to help people worship in } \\
\text { their alone time. }\end{array}$ & $\begin{array}{l}\text { "It can happen that I worship by myself and in the past days I started to } \\
\text { discover that I can listen to worship at home. In this case I learn to consume } \\
\text { it. I also create music ad have encounters with God when I play music. But } \\
\text { I realized that it is also very valuable for me when I listen to music, listen to } \\
\text { worship, and let it influence me. And I guess this is the best medium for me } \\
\text { to connect to God." }\end{array}$ \\
\hline $\begin{array}{l}\text { L4 } \\
\text { DRY }\end{array}$ & $\begin{array}{l}\text { But it is not necessary to use extra help, like digital music, to enter the } \\
\text { worship practice. It is perfectly possible to sing a capella or use one's own } \\
\text { instruments to worship God when doing so alone. This I label } d r y \text { worship } \\
\text { because it occurs without any outside help. }\end{array}$ & $\begin{array}{l}\text { "Producing music is almost like an instrument that I can give to God as a } \\
\text { sacrifice. I often do this with music that is playing. But it can take three } \\
\text { forms: playback, with a band or all alone without anything else playing. A } \\
\text { fourth option would be to worship with others and bringing that before } \\
\text { God." }\end{array}$ \\
\hline $\begin{array}{l}\text { L3 } \\
\text { IN COMMUNITY }\end{array}$ & $\begin{array}{l}\text { The classic worship endeavors occur with other people, either in a } \\
\text { spontaneous gathering or in a deliberate meeting. This can be a worship } \\
\text { event, a regular church meeting or a house-group gathering. }\end{array}$ & $\begin{array}{l}\text { "At this event, there were } 13,000 \text { people from Germany, Austria and } \\
\text { Switzerland. And in front of all these people I was playing the guitar with a } \\
\text { worship band. While playing, I felt really inspired. The situation had such } \\
\text { an extraordinary depth. To praise God with so many people at a famous } \\
\text { place and to put God in the center. [...] This was such an epic moment." }\end{array}$ \\
\hline $\begin{array}{l}\text { L4 } \\
\text { LEADING, } \\
\text { CO-LEADING, } \\
\text { PARTAKING }\end{array}$ & $\begin{array}{l}\text { When one worships in a community with other believers, often there is } \\
\text { someone or a team who is leading the musical happening and the worship } \\
\text { process. One can hence be a part of this leading process to facilitate the } \\
\text { ceremony. If one is not the sone musical leader, one can be a part of the } \\
\text { team and therefore be a co-leader for the worship endeavor. Last but not }\end{array}$ & $\begin{array}{l}\text { "Worship with other people [in the church] is a form of "corporate worship'. } \\
\text { [...] However, in solitude I experience this "celebrating God' less."; "When } \\
\text { I am playing music [in a service] I have an additional responsibility. This } \\
\text { makes it more difficult for me to have an experience with God. Because } \\
\text { there is much thinking standing in the way."; "I distinguish the situation }\end{array}$ \\
\hline
\end{tabular}


least, since not all people can be leading the practice, most of the people will follow along and partake in the ceremony.

\begin{tabular}{|c|c|}
\hline $\begin{array}{l}\text { L3 } \\
\text { POSTURE }\end{array}$ & $\begin{array}{l}\text { There is not one predetermined physical posture in which one has to be in } \\
\text { a worship practice. Instead, it can take many forms. }\end{array}$ \\
\hline $\begin{array}{l}\text { L4 } \\
\text { STANDING, } \\
\text { SITTING, } \\
\text { LYING, } \\
\text { DANCING }\end{array}$ & $\begin{array}{l}\text { There are a whole host of postures from which one can worship. Often in } \\
\text { a church setting, it is customary to stand while singing but just as } \\
\text { frequently, people are sitting on a chair to dive into the practice. More } \\
\text { rarely and rather to be found among charismatic denominations, } \\
\text { sometimes believers are lying on the floor or dancing around when doing } \\
\text { worship. }\end{array}$ \\
\hline $\begin{array}{l}\text { L2 } \\
\text { PHYSICAL } \\
\text { ENGAGEMENT }\end{array}$ & $\begin{array}{l}\text { There is always some sort of physical engagement present in any given } \\
\text { activity, be it religious or not. This is no different when it comes to } \\
\text { worship. }\end{array}$ \\
\hline
\end{tabular}

L3

ACTIVE

When in a worship endeavor, it is usually the case that the person has an active physical engagement. This means that the worshipper does something with his or her body. Whatever one actively does to the glory of God is effectively seen as an act of worship.

\begin{tabular}{l|}
\hline L4 \\
SINGING \\
\\
\hline L4 \\
PLAYING \\
INSTRUMENT AN
\end{tabular}

The most classic forms of all is to be singing, either alone or in community with others. Like this, one uses one's voice to glorify God and to give him compliments. This is a dialogue with the divine, effected by musical means.

A similar engagement with worship is possible, not only with one's voice

INSTRUMEN

as the primary instrument but with other musical instruments. This can be any instrument imaginable, like the guitar, the base, the piano, the keyboard, the drums, or whatever. If one plays the instrument to honor God, then it is an act of worship.

\begin{tabular}{l|l}
\hline L4 & One can also move one's body with the intention to give God the glory.
\end{tabular}

DANCING

This can occur either alone, in community, in a ceremony, or on a professional stage.

\begin{tabular}{l|l} 
L4 & In recent years, it has become more customary in some evangelica
\end{tabular}

PAINTING where I am leading worship for others or simply for myself. "; "In corporate worship you are dependent on the leadership. It means that if I don't know the song, it is a lot harder to immerse myself in worship."

"It's not important for me if it is light or dark in the room. The light - or also whether I am standing or sitting - does not make a difference for me."

"I was once in worship ceremony where I was sitting on a seat and it was hard to push through. And then it was helpful that I left the setting. So, I thought to myself: let's go to the back of the hall and lay on the floor. There I can spend time with God. I changed the setting and then it worked. But I don't have a formula where I could say: three forward rolls, two hand claps and then he is here."

"I don't think that I can worship without physical expression. But this has to do with the fact that singing is also an exercise for me. It is like doing sports - or dancing. I can't be without dancing for too long. The same with singing. After a while, my body has the urge to sing, to use my voice, to use this organ.

"For me it is important to be physically active during worship times. This is why I can't understand people that do not move around when they worship."; "It is really hard for me to find a connection when I am not active."; "I was always of the opinion that it also works with my inner voice. But the realization came that now it has to get out."

"The preacher told us that there are several ways to worship and praise God. You can paint, you can pray, you can sing, you can act or be artistic."; "It is really helpful for me to sing. And it can also happen that I stop again. But to get into the worship atmosphere and to connect, it helps to do it actively."

"Another form of worship for me - since I am a musician myself and am playing the guitar - is to play the guitar during the worship ceremony."

"It's not important for me if it is light or dark in the room. The light - or also whether I am standing or sitting - does not make a difference for me."

"Worship can mean to say who God is for me. But it can also mean that I use my gifts for him. [...] It can also consist of drawing and painting. It is mainly to use the gifts that we have. And therein to give God the glory."; "I believe that musical worship is a part of our creative being. It's about creating something. Worship can hence be many things at once: all artistic things - and art is not just restricted to dancing or painting, it is extremely 
to paint can come up front and create a painting. The logic for this is the following: if we can praise God with creative means such as our voices, instruments and with dancing, then we can also worship him with other creative methods like painting.

\section{L4}

READING,

ACTING

\section{L3}

PASSIVE

L3

NONE

(ONLY MENTAL)

By this token, every active engagement performed to the glory of God can become a form of worship. In the church congregations, this can also become immanent by reading texts together and also by acting plays with a specific message.

When thinking about worship, often active physical modes come to mind. This, however, is not necessarily the case. It is also possible to restrain from physical engagement and be passive. This means that one chooses not to be physically active but to be still whereas one has only a menta engagement. One may be sitting, lying, standing, or whatever one pleases but at this moment, the practitioner choses to not be active in a physical sense. This then comes close to a meditative state.

\section{L2 \\ PSYCHOLOGICAL}

ENGAGEMENT

L3

ACTIVE

While, of course, worship practices can be affected physically, they are first and foremost a psychological practice. Without the psychological engagement, one cannot say that the practice can properly be called worship.

Often, worship is seen as an active mental process where one deliberately activates cognitive and emotional mechanisms to honor God.

L4

SEEKING GOD

Nome nest omen, one of the prime goals for the worshipper usually is to connect with God and as such, the mental framework aspired by the believer is one of seeking after him. Worship and the musical setting then is a means to this end.

L4

DOGMATIC

ENGAGEMENT

There is an intellectual element to all of this since when one sings or actively engages with a practice on a mental level, then one cannot avoid being confronted with theological ideals, virtues, dogmas, and beliefs. In the ceremony, these are regularly reflected upon.

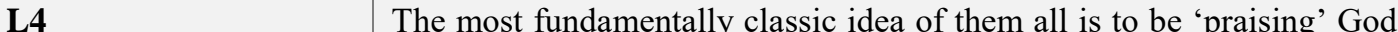

PRAISING When one thinks of worship, normally one thinks of being in a state of mind where one is praising and honoring God. Most of the time, this is a linguistic (verbal) process, either spoken out loud or done so only in one's mind. broad. Here it's about our creative essence. By making music as a creative act we are making a step towards God."; "The preacher told us that there are several ways to worship and praise God. You can paint, you can pray, you can sing, you can act or be artistic. Just ask him [Jesus]: what's the deal today? How should we praise you?"

"The preacher told us that there are several ways to worship and praise God. You can paint, you can pray, you can sing, you can act or be artistic. Just ask him [Jesus]: what's the deal today? How should we praise you?"

"Yes, sometimes worship for me is passive. I just let myself be irrigated. I don't do much [in these situations]. I become still. I just let myself be offered to by God as I try to receive. I absorb the music and also the text."; "The deepest times for me are when I am still, look at him and just want to be with him. I then try to think about Jesus visibly. This really helps me because usually I am easily distracted. In such times I let God speak and listen what he thinks about me, about life and he shows me things. This is how I experience God the strongest."

"I often experience God, well, more than $50 \%$ of every time I worship. So, when I actively engage in worship [mentally], I encounter God in more than $50 \%$. [...] I think it really has to do with what attitude I engage with worship music."

"One possible form of worship is that I am active and intensively try to sing along and thereover I attempt to search for God and to pray to him in worship. To praise him with my own words, like in the Psalms. Regardless of my momentary situation I say: 'Here I am and I praise you. I seek you."' "One possible form of worship is that I am active and intensively try to sing along and thereover I attempt to search for God and to pray to him in worship. To praise him with my own words, like in the Psalms. Regardless of my momentary situation I say: 'Here I am and I praise you. I seek you."' "We can listen and enjoy the moment. We can think about certain impressions and statements. We can reflect them intellectually therein [in taking time to focus on God]. To me, this is also a form of worshipping God."

"To praise him with my own words, like in the Psalms. Regardless of my momentary situation I say: 'Here I am and I praise you."; "I think this should be the motivation in worship: I honor God in the service. That's worship." 


\begin{tabular}{|c|c|c|}
\hline $\begin{array}{l}\text { L4 } \\
\text { REJOICING }\end{array}$ & $\begin{array}{l}\text { Although it is perfectly legitimate to have seasons of lamentation, worship } \\
\text { is generally viewed as a process where associates positive cognitions with } \\
\text { the divine and hence rejoices either for who God is or for what he is doing } \\
\text { (or has done). }\end{array}$ & $\begin{array}{l}\text { "Another intense experience was at a worship ceremony in the US. I was } \\
\text { rejoicing so much and I was able to dance. Normally I am not the most } \\
\text { extroverted person like others. But there I felt like King David who was } \\
\text { rejoicing in front of the ark of the covenant." }\end{array}$ \\
\hline $\begin{array}{l}\text { L3 } \\
\text { PASSIVE }\end{array}$ & $\begin{array}{l}\text { Even before the dawn of Christianity, contemplative meditation has been } \\
\text { a popular religious practice. It has also found its way in Christian forms } \\
\text { of worship. This is not an active psychological engagement but a passive } \\
\text { one, meaning that one is attempting to remain calm and to get into a } \\
\text { receptive mood where one allows God to come closer and to bestow his } \\
\text { gifts on us humans. }\end{array}$ & $\begin{array}{l}\text { "I would say that when I worship passively, then it feels a lot more peaceful } \\
\text { and calming. And when I do it actively, I do it with more enthusiasm and } \\
\text { empathy." }\end{array}$ \\
\hline $\begin{array}{l}\text { L4 } \\
\text { LISTENING }\end{array}$ & $\begin{array}{l}\text { To many believers, prayer is not just a giving process where one utters } \\
\text { words but it can also be a receiving process where one listens to what God } \\
\text { has to say. This is equally true in worship. }\end{array}$ & $\begin{array}{l}\text { "But I realized that it is also very valuable for me when I listen to music, } \\
\text { listen to worship, and let it influence me. And I guess this is the best medium } \\
\text { for me to connect to God." }\end{array}$ \\
\hline $\begin{array}{l}\text { L4 } \\
\text { RESTING }\end{array}$ & $\begin{array}{l}\text { Even more so than in classical meditation, some worshippers set out to } \\
\text { enter the worship ceremony to deliberately calm down and rest. They } \\
\text { hope to experience God in the rest, the stillness and the calm. }\end{array}$ & $\begin{array}{l}\text { "Yes, when I experience God in worship is it a passive thing. I just let it } \\
\text { flow over me. I don't do much. There I am almost still. I just let God to give } \\
\text { his things to me I and I try to receive it. I absorb the music and also the } \\
\text { lyrics. Then I just say: 'God, there I am. Minister to me.", }\end{array}$ \\
\hline $\begin{array}{l}\text { L4 } \\
\text { SOAKING }\end{array}$ & $\begin{array}{l}\text { One special form of resting has been referred to as soaking. This is more } \\
\text { than just staying in rest but here one deliberately wants to find God in a } \\
\text { passive attitude and literally soak up his presence. The hope is to gain a } \\
\text { tremendous religious experience from the practice. }\end{array}$ & $\begin{array}{l}\text { "I worship God daily. Sometimes in formations where I have bands to } \\
\text { worship. But also, But also during the soaking group on Monday } \\
\text { evenings..." }\end{array}$ \\
\hline $\begin{array}{l}\text { L1 } \\
\text { EXPERIENCE }\end{array}$ & $\begin{array}{l}\text { Perhaps one of the most interesting topics revolving around religious } \\
\text { worship practices is the topic of religious experience in worship. The } \\
\text { emergent categories explain where they occur, how they are perceived, } \\
\text { and by which means they are induced. }\end{array}$ & $\begin{array}{l}\text { "I definitely sense God [in worship]. I can feel his spirit. I feel if God is } \\
\text { working in the hearts of men or not. Sometimes I feel what he is doing. Let } \\
\text { me bring an example: sometimes I realize that there is a lot of freedom in } \\
\text { the room. This is definitely God who sets this free." }\end{array}$ \\
\hline $\begin{array}{l}\text { L2 } \\
\text { SETTING }\end{array}$ & $\begin{array}{l}\text { One key question here is: are worship experiences inherently individual } \\
\text { experienced or are they a collective phenomenon? The answer: they can } \\
\text { be both - intimate and communal. }\end{array}$ & $\begin{array}{l}\text { "So on the one hand, worship surely is something that is intimate. } \\
\text { Something you do [yourself] for God. But there is also a communal aspect. } \\
\text { There you realize that you are one with others before God." }\end{array}$ \\
\hline $\begin{array}{l}\text { L3 } \\
\text { INTIMATE }\end{array}$ & $\begin{array}{l}\text { Most of the times, especially when worshipping alone, it is reported to be } \\
\text { a tremendously intimate experience. It is an experience of being } \\
\text { connected to God in an "i-and-God" fashion. }\end{array}$ & $\begin{array}{l}\text { "I feel that I can steer myself where I want to get when I am doing worship } \\
\text { by myself. Then I select the songs I know and I am less distracted by other } \\
\text { people. Like this I can find peace much better and I feel more connected } \\
\text { with God." }\end{array}$ \\
\hline $\begin{array}{l}\text { L3 } \\
\text { COMMUNAL }\end{array}$ & $\begin{array}{l}\text { Sometimes, and only when worshipping with other people, it can be } \\
\text { conceived as a communal experience. It is still intimate but in an enriched } \\
\text { sense, namely that one feels both one with the people around them as well } \\
\text { as one with God. This is an experience in a "we-and-God" fashion where } \\
\text { a person feels connected to others and everybody present (the worshipper } \\
\text { and the people around who are also worshipping) are altogether connected } \\
\text { to God. }\end{array}$ & $\begin{array}{l}\text { "So, on the one hand, worship surely is something that is intimate. } \\
\text { Something you do [yourself] for God. But there is also a communal aspect. } \\
\text { There you realize that you are one with others before God. Just this unity in } \\
\text { the community which emerges in communal worship: you come to God with } \\
\text { so many others and all are loved, all are appreciated, all are creatures of the } \\
\text { lord. There occurs such a justice in the moment which I personally like a lot } \\
\text { and which I feel is lacking when it's not there. This worship with the Body }\end{array}$ \\
\hline
\end{tabular}




\begin{tabular}{|c|c|c|}
\hline & & $\begin{array}{l}\text { of Christ. So far, we have talked about the personal aspects of worship. But } \\
\text { that's an important aspect that we are in the same boat with others. And this } \\
\text { is something that joins us together." }\end{array}$ \\
\hline $\begin{array}{l}\text { L2 } \\
\text { PHENOMENOLOGY }\end{array}$ & $\begin{array}{l}\text { It is interesting to ask about the phenomenal qualities of such experiences. } \\
\text { How are religious experiences in worship being perceived? There are four } \\
\text { ways how they can occur: emotional, physical, hybrid and } \\
\text { epistemological experiences. }\end{array}$ & $\begin{array}{l}\text { "Hmm, these experiences can be very diverse for me. It can be that I } \\
\text { experience a strong calmness. It can also be heavy-laiden, so that I cannot } \\
\text { move. My muscles are becoming really relaxed and they can't move because } \\
\text { it's such a pleasant state. But it can also go the other way: I can become } \\
\text { rather nervous and my body jerks and shivers." }\end{array}$ \\
\hline $\begin{array}{l}\text { L3 } \\
\text { EMOTIONAL }\end{array}$ & $\begin{array}{l}\text { For the most part, divine worship experiences are conceived as inherently } \\
\text { emotional. They can be exclusively emotional or emotional with an added } \\
\text { element of another category (e.g. physical or epistemological). }\end{array}$ & $\begin{array}{l}\text { "And yes, it's emotional as well. Something happens with me. Because I } \\
\text { realize that it's supernatural. This is something so beautiful and valuable. } \\
\text { And this touches me so strongly every time in my heart." }\end{array}$ \\
\hline $\begin{array}{l}\text { L4 } \\
\text { FEELING } \\
\text { FULFILLED }\end{array}$ & $\begin{array}{l}\text { Having the sentiment that this is as pleasant and good as it can possibly } \\
\text { be. }\end{array}$ & $\begin{array}{l}\text { "One of the most beautiful experiences I ever had was this coupled } \\
\text { fulfillment. I remember it vividly; it was at a worship event. There I felt so } \\
\text { saturated - I can remember it well - that I thought to myself, if God would } \\
\text { say to me: 'This is all that I have for you; it's not gonna get better. This is } \\
\text { the climax.' And then I would think: it's good like this. I would no lack a } \\
\text { thing in the moment." }\end{array}$ \\
\hline $\begin{array}{l}\text { L4 } \\
\text { FEELING } \\
\text { ACCEPTED BY GOD }\end{array}$ & Sensing that God unconditionally accepts, welcomes, and embraces us. & $\begin{array}{l}\text { "It's a emotional state of peacefulness. A state of peace, stillness and } \\
\text { absolute harmony - everything is just ok. Then you have the feeling that you } \\
\text { are at the right place. Maybe a feeling of home. Of love, a state of unearned } \\
\text { acceptance - and this is also a state where you realize: you are not enough; } \\
\text { it's not something you can buy; you can work to get it; but it comes from } \\
\text { this outside and surrounds you. It is something extremely positive. It's free } \\
\text { from anything negative. It's a state of absolute fulfillment." }\end{array}$ \\
\hline $\begin{array}{l}\text { L4 } \\
\text { FEELING } \\
\text { HARMONY }\end{array}$ & $\begin{array}{l}\text { One can either feel in harmony with oneself (feeling integrated), with } \\
\text { nature and the surroundings, with other people, or all of them together. } \\
\text { The primary stages of this sensation is a feeling of harmony and the latter } \\
\text { stages are sensations of unity. }\end{array}$ & $\begin{array}{l}\text { "It's a emotional state of peacefulness. A state of peace, stillness and } \\
\text { absolute harmony - everything is just ok. Then you have the feeling that you } \\
\text { are at the right place. Maybe a feeling of home. Of love, a state of unearned } \\
\text { acceptance - and this is also a state where you realize: you are not enough; } \\
\text { it's not something you can buy; you can work to get it; but it comes from } \\
\text { this outside and surrounds you. It is something extremely positive. It's free } \\
\text { from anything negative. It's a state of absolute fulfillment." }\end{array}$ \\
\hline $\begin{array}{l}\text { L4 } \\
\text { FEELING } \\
\text { LOVE }\end{array}$ & $\begin{array}{l}\text { This is a difficult cluster because it is not clear if everybody feels God's } \\
\text { love in a comparable way. However, there is a core to the experience } \\
\text { because people who report this feeling show unanimity in their knowledge } \\
\text { that this is a sensation of his love. }\end{array}$ & $\begin{array}{l}\text { "I think perhaps feeling God's presence is like when you're in love for the } \\
\text { first time. This adrenalin. This is also like the moment where you give your } \\
\text { life to God for the first time. There is rarely a moment where one realizes } \\
\text { this intensely: something has changed." }\end{array}$ \\
\hline $\begin{array}{l}\text { L4 } \\
\text { FEELING CLOSE TO } \\
\text { GOD }\end{array}$ & $\begin{array}{l}\text { There are times where people do not sense the presence of God. In such } \\
\text { cases, they feel far away or even abandoned by him. Worship, however, } \\
\text { can elicit the sentiment that one feels close with him again. }\end{array}$ & $\begin{array}{l}\text { "Yes, my main motivation for worship is to sense God's presence. [...] I } \\
\text { just realized: in worship there is this dimension of God's involvement } \\
\text { present."; "How do I sense God's presence in worship? Oh, it is very real! }\end{array}$ \\
\hline
\end{tabular}




\begin{tabular}{|c|c|c|}
\hline & & $\begin{array}{l}\text { In worship, I can encounter God vividly with my inner eyes as I get the } \\
\text { feeling that there is an intimacy with God. And then I am a little closer to } \\
\text { god as opposed to my normal state. Not that I would feel disconnected or } \\
\text { that he would be absent there. But in worship I feel that he is closer. It's like } \\
\text { amongst family and friends: when you don't see each other for a while, you } \\
\text { still know that they are somewhere and you could call them anytime and } \\
\text { hence be a little bit closer to them or meet them. I think the same is true for } \\
\text { worship." }\end{array}$ \\
\hline $\begin{array}{l}\text { L4 } \\
\text { FEELING IN UNITY } \\
\text { AND INTIMACY } \\
\text { WITH GOD }\end{array}$ & $\begin{array}{l}\text { When one does not only feel close to him but absorbed or deeply } \\
\text { connected to God, then there is a sense of unity and intimacy which one } \\
\text { experiences in this moment. }\end{array}$ & $\begin{array}{l}\text { "I really experience God in worship through this unity and connectedness } \\
\text { or that he awakens me from my thoughts." }\end{array}$ \\
\hline $\begin{array}{l}\text { L4 } \\
\text { FEELING IN UNITY } \\
\text { AND INTIMACY } \\
\text { WITH OTHERS }\end{array}$ & $\begin{array}{l}\text { The same can occur not only with God but also with other people in the } \\
\text { community. This is then both an intimate as well as a communal } \\
\text { experience. The difference with the above category (experience } \rightarrow \text { setting } \\
\rightarrow \text { communal) is that here it is not a "I feel like we are all together } \\
\text { connected to God) but rater a "I feel deeply one with the others around } \\
\text { me". }\end{array}$ & $\begin{array}{l}\text { "Well, I think on the one hand it's that as a band or as a worship leader, we're } \\
\text { kind of a unity and we go together for what God does. That's one way we } \\
\text { experience God as a whole band: that we know 'as one' that this is } \\
\text { something God does. And sometimes you feel it more and sometimes less. } \\
\text { But I often experience that when the presence of God is there, he gives } \\
\text { something to individual people and then you go for it together." }\end{array}$ \\
\hline $\begin{array}{l}\text { L4 } \\
\text { FEELING } \\
\text { TIMELESSNESS }\end{array}$ & $\begin{array}{l}\text { In a deep mystical experience through worship, sometimes the senses } \\
\text { become blurry and one loses the pace of time. Time appears to be standing } \\
\text { still and only the moment counts as it is absorbing everything at this point } \\
\text { in time. }\end{array}$ & $\begin{array}{l}\text { "I believe that on the one hand music helps to be in the here and now. And } \\
\text { it picks me up from doing and brings me into being. On the other hand - by } \\
\text { the way, I not only experience this in music, but also when I walk through } \\
\text { the forest or something [similar] - I have the feeling that I have flash } \\
\text { moments. I feel the connection of the whole world and all generations. I } \\
\text { have the feeling that music can do that. For me, a walk in the forest can do } \\
\text { that as well. The music manages to bring me into the moment and at the } \\
\text { same time it creates something timeless. And I find that special. It helps me } \\
\text { to perceive the moment and at the same time it helps me to open myself to } \\
\text { what happens above this moment: what comes before and after." }\end{array}$ \\
\hline $\begin{array}{l}\text { L4 } \\
\text { RECEIVIG } \\
\text { 'IMPRESSIONS' }\end{array}$ & $\begin{array}{l}\text { A classic religious experience - also in worship - amongst charismatic } \\
\text { churches is that a believer get an impression. This is when one receives a } \\
\text { so-called prophetic sentiment, meaning that one is having words for } \\
\text { oneself or for others. These words are believed to be directed by God and } \\
\text { sometimes they come along with a specific task (like knowing that one } \\
\text { should pray for a specific person). }\end{array}$ & $\begin{array}{l}\text { "I found that exciting and did that once. I asked God how he wanted to be } \\
\text { worshipped. His answer was: 'Just let me love you.' I found that exciting } \\
\text { because that was not a thought I would come up with on my own."; "It may } \\
\text { also be that God puts something on my heart that I don't normally have on } \\
\text { my heart. This makes me pray very hard for something. For example, } \\
\text { intercession. One category of these experiences is related to myself. But } \\
\text { another one is also that I stand for something else. That God moves me to } \\
\text { stand up for something else where it is not about me." }\end{array}$ \\
\hline $\begin{array}{l}\text { L4 } \\
\text { HAVING } \\
\text { SENTIMENTS }\end{array}$ & $\begin{array}{l}\text { These are regular or classic emotions we know from everyday life but are } \\
\text { evoked in a worship setting. It often coincides with a feeling that the heart }\end{array}$ & $\begin{array}{l}\text { "Such experiences always include that my heart or my emotions are } \\
\text { involved and being spoken to."; "I would say that I have already experienced } \\
\text { God. Emotionally but also rationally. Emotionally in the sense that }\end{array}$ \\
\hline
\end{tabular}


is touched. These are things like having joy, melancholy, being refreshed, feeling heavy, a sense of urgency.

L4

FEELING A DIVINE

CALMNESS

L4

FEELING DIVINE

FREEDOM

L4

\section{DELIVERANCE}

L4

\section{CLEANSING}

L4
FEELING DIVINE
JOY

L4

EMOTIONAL

HEALING
Daily life can become very busy and the thoughts may be scattered all over the place. Rest, stillness, and calmness are not always on the forefront of the modern life. However, in worship people can settle down and experience a calmness which is difficult to achieve otherwise.

An even stronger form of experience than feeling a divine calmness is to sense a divine freedom. Here, one does not only feel still but finally at peace. This peace can be with oneself but also with others and with God.

As a consequence of the worship endeavor, a person may become delivered from pain, sorrows and suffering. This new-found freedom can also lead to feeling freed to get into the presence of God.

As humans, we may have all sorts of regrets in our lives and some of them are subsumed under the term sins that make people feel guilty or unworthy. One experience similar to deliverance is that one senses to be cleansed and forgiven. This is a spiritual ne found freedom which one can enjoy once or regularly.

There may be joy but there may also be a superlative joy of such strong euphoric degree that it is interpreted as inherently divine.

On a psychological note, when some worshippers believe to have an encounter with God, they may get out of the experience with a sense that they are now healed from their initial despair and brokenness. This is considerably helpful for people to cope with their past and what they feel to be present inadequacies. sometimes I had to cry. Then I had the feeling that God came upon me with his love. With a love that surpasses understanding. It was almost unbearable already, so that I broke out in tears. But not negatively, but because it was so beautiful. And then I realized that there was something beyond the radius than I could control. I would say that this is something superior. I realized that I could not prove this rationally, but through empirical experience I realized: hey, this is clearly from God. This coincides for me with the intellect, because it is in accordance with what I read in the Bible. I read in the Bible what God must be like and then there is my emotional experience where I realize that this coincides."

"Sometimes in worship I get pleasantly calm."; "I experience God differently during the worship times. It can be that I encounter an extreme stillness."

"I feel this anointing as freedom, yes, that's true. But it's also a power that comes as an intensity while singing."; "This divine freedom is something lite that I sense in the moment. I feel the pressing things but also the lite ones."

"I have often experienced that he takes away my sorrows and that he takes away the weight on my heart. There I feel that he takes it from me. And there I get out of the experience very differently."

"It has something to do with Catharsis. There are also moments of prayer in daily life, where situative worship moments just happen."

"Sometimes during worship, I experience a joy or a freedom."; "This is something very tender. It's almost uncalled for. Why am I now more happy than before? This is such a radical shift that can occur."

"I have experienced something that has triggered a great gratitude for God in me. He healed a certain wound in me that I had had for years, but I was not aware of it. I went home and was freed from it. I picked up the guitar, sat on the carpet and wanted to say thank you to God. I used to be so pragmatic: I knew God died for me on the cross. But emotionally it had meant nothing to me. And that evening I thanked him for it. And there I burst into tears, because I really meant it. And in the tears I could worship God. That's what I've always wanted. And that really changed a lot in my life." 
"It may also be that God puts something on my heart that I don't normally have on my heart. This makes me pray very hard for something. For example, intercession. [...] The experience has different emotional expressions: that you have a great joy inside. Or that you become very melancholic. Just as the psalms have different faces. These states can also happen in worship. That I am sometimes very sad..."; "Sometimes I start to cry. Or - it is difficult to describe: sometimes it comes like a pain without anything hurting. That is like a reaction, it can be related to such a tense reaction. A reaction like the one you would have if the sound was too loud. Or a bright light. But without the painful, the unpleasant component."

L4

MENTAL CHANGE

L4

FEELING ECSTATIC

Feeling ecstatic in worship is best described in the words of an interviewee: "It is not unlike when you smoke weed." (Transcript 14)

This is a significant paradigm shift that may occur after the worship endeavor. It is when one comes out different from the experience than one gets in. Often, one sees the world in a better light and filled with more purpose.

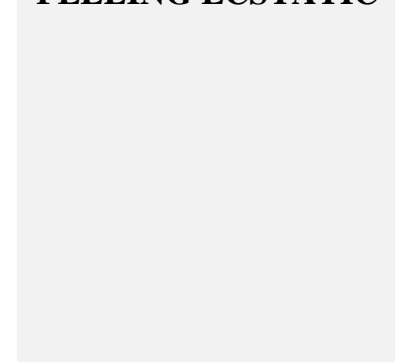

L4

BEING

OVERWHELMED BY

GOD
One can feel overwhelmed by God in a physical or in an emotional sense.

The latter is an experience where one believes to experience God's glory or greatness to a degree that one can barely emotionally take it in.

\section{L3}

\section{PHYSICAL}

Religious experiences in worship can be physical in nature, meaning that there are bodily reactions associated with them or at least, one believes them to be of this sort.
The takes away my worries, that he relieves my heavy heart. There I sense him taking it from me. And then I leave this experience with a very different mindset."

"Sometimes it is similar to an ecstatic excitement. Like adrenaline when you are nervous. This feeling in the stomach like a nervousness. Sometimes it's like when the skin tingles. By the way, smoking pot is not dissimilar. This is a near fake. At least that's how I feel about it. Although, someone else once described it to me who has smoked much more than I have. It's often like that: when I feel God in my everyday life, it has a lot to do with this feeling. [...] It's just so cloudy, fluffy, like skin sensations. Something spongy like that. It is also a bit dizzy. It is still difficult to make sense of it, because it is always very different. [...] Yes, but in a very pleasant way. Not bad at all. It is something cheerful. Like when you sit in the sun and drink two beers."

"Often it is a bodily sensation. But sometimes, it can also be a very strong emotional reaction. It can come both at once. [...] Yes, I describe it as so intense because I have no other comparison to it. But I experience it as positive and real. [...] It is an emotional sensation of being overwhelmed [by God]. And I realized that such moments have a positive effect on me. And that's why I associate them positively. [...] Although it's extremely difficult to describe such an intense positive experience if we're not using the example of sex [laughes]. But this would be a little strange in this context."

"I have also already experienced that I could not stand up again; as if I had stepped away. There I became physically weak. I was so completely emotionally and physically overwhelmed that I could simply not get up. I also fell off the piano chair [laughs]. These experiences can be incredibly intense. [...] The funny thing is: it's never negative or scary. And you also 


\begin{tabular}{|c|c|c|}
\hline & & $\begin{array}{l}\text { know: you could fight it and then you could stand up again. It's more like } \\
\text { being completely overwhelmed and then you enter the state voluntarily. And } \\
\text { if there are people, like our pastor, who are a bit embarrassed about it - he } \\
\text { finds it extremely unpleasant - then it's not for him; but for me it's different, } \\
\text { it's funny. The way I have experienced it so far is to view it as something } \\
\text { desirable. It is a sign: ok, something is happening here. When people begin } \\
\text { to manifest or fall over, it is linked in people's minds with: oh cool, God is } \\
\text { doing something. Or something extraordinary is happening. A lot of this } \\
\text { coincides with spontaneous healings, etc. With prophetic impressions and } \\
\text { someone starts to cry because this has spoken into his life. And then you } \\
\text { think: wow, cool, there is an atmosphere where God has room to do things. }\end{array}$ \\
\hline $\begin{array}{l}\text { L4 } \\
\text { BEING } \\
\text { OVERWHELMED BY } \\
\text { GOD }\end{array}$ & $\begin{array}{l}\text { Being physically overwhelmed by God is an experience often sought after } \\
\text { by young evangelicals. It is believed to be a powerful experience where } \\
\text { one senses God's power to such a strong degree that one loses control } \\
\text { over one's body. These things are often referred to as 'manifestations'. } \\
\text { They can come in many forms: a person may fall to the ground, losing } \\
\text { one's strength, shivering, shaking, or trembling. }\end{array}$ & $\begin{array}{l}\text { "I've seen it happen several times that I held my arms up and suddenly I } \\
\text { couldn't put them down myself. I tried, but I felt a resistance. I could not do } \\
\text { it either way, it kept pulling my arm up. I experienced this about three times. } \\
\text { For me, that is like a [divine] handshake. Then the arm is up for half an hour } \\
\text { and I forget about it. And so I continue to worship God. I then become } \\
\text { neither tired nor weak."; "And I can also remember one event, it was so } \\
\text { crazy: I couldn't stand up on my feet. It really pushed me down to my knees } \\
\text { because it was so overwhelming." }\end{array}$ \\
\hline $\begin{array}{l}\text { L4 } \\
\text { ORDINARY } \\
\text { SENSATIONS }\end{array}$ & $\begin{array}{l}\text { These are sensations we often experience but here they are induced in a } \\
\text { worship setting. They may be things like feeling refreshed, energized, } \\
\text { strengthened, heavy-laden*, or relaxation. } \\
\text { (*This heaviness is often associated with positive emotions since they are } \\
\text { thought of being a product of experiencing God's glory) }\end{array}$ & $\begin{array}{l}\text { "And sometimes I feel it on my skin. On my body, that something is } \\
\text { different. That the air feels differently."; "Very often I experience that I am } \\
\text { mentally or even physically refreshed. It gives me something: a holistic } \\
\text { energy to move forward in life." }\end{array}$ \\
\hline $\begin{array}{l}\text { L4 } \\
\text { EXTRAORDINARY } \\
\text { SENSATIONS }\end{array}$ & $\begin{array}{l}\text { Apart from ordinary sensations which we may also experience in daily } \\
\text { life without a worship context, there are also extraordinary ones. They are } \\
\text { almost like the above-mentioned manifestations but not as overwhelming } \\
\text { in their force to come upon the experiencer. Examples are: feeling an } \\
\text { electrical current (like a tickling) on one's hand or in the body, feeling an } \\
\text { invisible hand on one's head or shoulders, sensing an anointing (like hot } \\
\text { oil), feeling a fabric or God's presence like a scarf on the skin, feeling a } \\
\text { flow of energy or power coming in or getting out of the body, feeling an } \\
\text { ostensible heat or coolness, or sensing a wind inside our outside of the } \\
\text { body. }\end{array}$ & $\begin{array}{l}\text { "... it was a very strong experience: I felt God's presence very tensely in the } \\
\text { whole room. That was certainly one of those experiences of about three that } \\
\text { come to my mind. The spirit was so thick in the room that you felt like you } \\
\text { could take out a knife and cut into it - that's how close the presence was in } \\
\text { the room. I still do not fully understand the exact meaning of this experience. } \\
\text { But about every minute or so, it was like a burst energy flowing through my } \\
\text { body. I cannot quite describe it. But it felt like a heartbeat pulsating through } \\
\text { me. And during the whole thing it felt like this was the heartbeat of God. } \\
\text { Now I don't necessarily believe that God took me into his heart and let me } \\
\text { feel the 'real' beat [laughs]. But for me it was still an extreme experience that } \\
\text { I still can't quite put into words. It had the air of: there is a lot of healing } \\
\text { here, a lot of breakthrough." }\end{array}$ \\
\hline $\begin{array}{l}\text { L4 } \\
\text { SENSING AN } \\
\text { ANOINTING OF GOD }\end{array}$ & $\begin{array}{l}\text { In the previous category, one example is that a person can sense an } \\
\text { anointing like oil on the body. However, there is also a different } \\
\text { experience which believer frequently associate with sensing God's }\end{array}$ & $\begin{array}{l}\text { "Yes, God's anointing comes with freedom. It is often also a power, how } \\
\text { should I explain this, such an intensity within me also during singing. I have } \\
\text { the feeling: I have to let it out now. It's really difficult to describe it. It can }\end{array}$ \\
\hline
\end{tabular}




\begin{tabular}{|c|c|c|c|}
\hline & & $\begin{array}{l}\text { anointing. It is the situation where it is believed to be standing in a special, } \\
\text { sacred, holy or "anointed" atmosphere. }\end{array}$ & $\begin{array}{l}\text { also be that it moves me to tears. Leading during the worship time in this } \\
\text { state is not always easy. But it's not that I lose control over it. What I am } \\
\text { singing touches me somewhere deeper than I am touched just like that. Uhm, } \\
\text { how do you describe divine anointing [laughs]? So, yesterday I also } \\
\text { experienced this anointing before we started with the worship evening. We } \\
\text { were very busy. And we were all pretty nervous - me probably the worst. } \\
\text { The band stood together and tried to pray; and it was just pretty bad [my } \\
\text { nervousness]. And after that, our church leader walked in and I said: 'Hey } \\
\text { [name of the pastor], can you pray a quick prayer of blessing?' And the } \\
\text { moment the people came on the stage behind us and we started to pray in a } \\
\text { circle, then there was a power coming from outside. It was as if from one } \\
\text { moment to the next you were plunged into a force field, so that I had to hold } \\
\text { on to something - luckily, the piano was behind me. Otherwise I would } \\
\text { probably have fallen to the floor. Perhaps it is something like this when I } \\
\text { speak of anointing. I do not always experience it with the same intensity, } \\
\text { however." }\end{array}$ \\
\hline $\begin{array}{l}\text { L4 } \\
\text { VISIONS, } \\
\text { AUDITIONS, } \\
\text { VISITATIONS }\end{array}$ & & $\begin{array}{l}\text { Although these experiences are reported every once in a while, they are } \\
\text { extremely rare to occur as a consequence of a worship practice. Visions } \\
\text { occur as visual images people appear to see with their eyes but which are } \\
\text { nor visible to others in the room. They may be called visual hallucinations, } \\
\text { although in these cases, they are believed to be directly inspired by God } \\
\text { as a message to humanity. Auditions are the same thing but not visually. } \\
\text { Instead, they occur auditorily. The most common experience (although } \\
\text { not common in absolute numbers) is to be hearing the voice of God telling } \\
\text { a message to the recipient. The last and least common experience of this } \\
\text { sort is to be having visitations. This is when a person appears to 'have a } \\
\text { visit' from an otherworldly plane. The classic example would be that a } \\
\text { person reports to have been visited by an angelic being coming to visit } \\
\text { with a message. All these experiences have in common that they come } \\
\text { along as messengers from a higher realm. }\end{array}$ & $\begin{array}{l}\text { "Sometimes I close my eyes and then I have the feeling that divine words } \\
\text { come from the very top left. It usually comes from there and they are very } \\
\text { bright. And when they come, they are so clear that I know: ok, this is from } \\
\text { God. Exactly, yes. I have also spoken to other people who have told me that } \\
\text { it comes from a certain direction." }\end{array}$ \\
\hline $\begin{array}{l}\text { L4 } \\
\text { MIRACULOUS } \\
\text { HEALINGS }\end{array}$ & I & $\begin{array}{l}\text { The showcase archetype of physical experiences deemed divine are called } \\
\text { miracles. These are things happening in nature which are thought to run } \\
\text { counter to the normal course of actions. Mostly in this category, believers } \\
\text { report to have experienced a healing. This is a physical ailment which is } \\
\text { believed to have originated from God and it often stands in the context of } \\
\text { prayer or worship. }\end{array}$ & $\begin{array}{l}\text { "I have also experienced many miracles. Especially in the area of provision. } \\
\text { When I had financial difficulties, I decided to trust him every day. And as } \\
\text { such, I have experienced many supernatural things. I received a thousand } \\
\text { bucks in my mailbox by an anonymous person. I did not have enough } \\
\text { finances, but I just received money every month. [...] I also told you before } \\
\text { the interview about the healing of my fiancé's hand. It was a spontaneous } \\
\text { healing of his hand, who had a shattered fracture of the carpal bone - by the } \\
\text { way, this is on YouTube under [title of the clip]. His hand was healed from }\end{array}$ \\
\hline
\end{tabular}




\begin{tabular}{|c|c|c|}
\hline & & $\begin{array}{l}\text { one moment to the next. Yes, and so I have often witnessed many miracles. } \\
\text { Sometimes they also occur during times of worship." }\end{array}$ \\
\hline $\begin{array}{l}\text { L3 } \\
\text { HYBRID }\end{array}$ & $\begin{array}{l}\text { Sometimes it is difficult to clearly distinguish emotional from physical } \\
\text { experiences since they can occur together and have elements of both. } \\
\text { These I call hybrid experiences because they are both emotional as well } \\
\text { as physical in nature. }\end{array}$ & $\begin{array}{l}\text { "Yes, it was really both - physical and emotional. Just, from a physical point } \\
\text { of view, this experience of a force field is really like running into a very } \\
\text { strong magnetic field. Then you feel something similar, as far as I know, } \\
\text { right? You can sense something. Like a vibration. It's like something is } \\
\text { working on you from the outside. It makes you resonate like strings on a } \\
\text { fiddle, but on the other hand, it also makes your hair stand up and your knees } \\
\text { start to shake. You feel so powerless and have the feeling that you are about } \\
\text { to fall down. But you can't say that it happens only on the outside. It is } \\
\text { definitely both. [...] oh man, it's so difficult to describe." }\end{array}$ \\
\hline $\begin{array}{l}\text { L4 } \\
\text { EMBODIED } \\
\text { SENTIMENTS }\end{array}$ & $\begin{array}{l}\text { Here we have emotional sentiments that are so vivid that they become } \\
\text { translated into bodily reactions. This may be that one is crying, laughing } \\
\text { or tearing up for joy or sadness. }\end{array}$ & $\begin{array}{l}\text { "Yes, in the Christian environment we hear again and again that God speaks } \\
\text { to us - through nature or through the Bible. With me it is mainly in worship. } \\
\text { It may be that I notice that he speaks to me in my thoughts. Or that I at least } \\
\text { assume that it is him who speaks to me in my thoughts. But this also happens } \\
\text { on an emotional or physical level. Depending on whether I am leading or } \\
\text { not, there are different scenarios. But it does something with my body } \\
\text { temperature or with my relaxation. There is also sometimes a peace or } \\
\text { acceptance that is difficult to explain rationally. I experience this in } \\
\text { worship." }\end{array}$ \\
\hline $\begin{array}{l}\text { L4 } \\
\text { SENSING } \\
\text { DIVINE }\end{array}$ & $\begin{array}{l}\text { Sensing the presence of God or a higher power is perhaps the most } \\
\text { frequent and generic experience of them all. They can also be physical } \\
\text { because they provoke reactions like goosebumps and tingling. }\end{array}$ & $\begin{array}{l}\text { "I experience this a lot in times of praise and worship. There I have the } \\
\text { feeling of sensing the presence of God."; "How I feel when I sense God? } \\
\text { Hmm, this is quite difficult to describe. I would describe it mainly with } \\
\text { peace and acceptance on an emotional level. Physically, it is either an } \\
\text { enormous warmth or just the opposite: a cool calmness. But it is really hard } \\
\text { to describe. But sometimes I felt an enormous warmth that I had all over my } \\
\text { body." }\end{array}$ \\
\hline $\begin{array}{l}\text { L4 } \\
\text { A SIXTH SENSE }\end{array}$ & $\begin{array}{l}\text { This may be either physical or emotional, both or neither. This category } \\
\text { is difficult to conceptualize because the participants usually report it to be } \\
\text { ineffable in regular terms. When they are asked whether they experience } \\
\text { God in one form or another, it is often professed that both categories do } \\
\text { not do justice to the experience because it is something new or other which } \\
\text { is superseding normal conditions. It is often held that divine experiences } \\
\text { occur with a sixth sense. }\end{array}$ & $\begin{array}{l}\text { "Yes, it is incredibly difficult to describe how I experience God. It is not the } \\
\text { sensation of goose bumps for me. It is not a tingling in my stomach either. I } \\
\text { would almost have to describe it as a sixth sense, where other senses can't } \\
\text { feel anything at all - and just this sixth sense tells me: [flicks] that's it; there } \\
\text { is God in it here. It's difficult: I do not like to connect it to any emotion. } \\
\text { Because calling it emotional seems very misleading. It's something } \\
\text { different." }\end{array}$ \\
\hline $\begin{array}{l}\text { L4 } \\
\text { THE HOLISTIC } \\
\text { EXPERIENCE }\end{array}$ & $\begin{array}{l}\text { The feeling that one's whole being and perhaps even the whole world is } \\
\text { involved in the experience. }\end{array}$ & $\begin{array}{l}\text { "I think in such experiences there arises an awareness of the 'bigger picture' } \\
\text { or the 'larger whole'. This does not imply that you think of all things } \\
\text { simultaneously. But then you become aware of the interconnectedness of all } \\
\text { things." }\end{array}$ \\
\hline
\end{tabular}




\begin{tabular}{|c|c|c|}
\hline $\begin{array}{l}\text { L4 } \\
\text { SENSE OF AWE }\end{array}$ & $\begin{array}{l}\text { With or without music, worship can induce a tremendous sense of awe } \\
\text { which sometimes also translates into strong gratitude. }\end{array}$ & $\begin{array}{l}\text { "I experience God in that I get new understanding about something and then } \\
\text { I am in total awe before him because it is a truth that I have just newly } \\
\text { discovered. Then it is an awe at how God is." }\end{array}$ \\
\hline $\begin{array}{l}\text { L4 } \\
\text { FEELING NERVOUS }\end{array}$ & $\begin{array}{l}\text { There is a tension and a tingly feeling which is described like when } \\
\text { someone is in love or when one is about to write an exam. }\end{array}$ & $\begin{array}{l}\text { "Sometimes it is similar to an ecstatic excitement. Like adrenaline when you } \\
\text { are nervous. This feeling in the stomach like a nervousness. Sometimes it's } \\
\text { like when the skin tingles. By the way, smoking pot is not dissimilar. This } \\
\text { is a near fake. At least that's how I feel about it. Although, someone else } \\
\text { once described it to me who has smoked much more than I have. It's often } \\
\text { like that: when I feel God in my everyday life, it has a lot to do with this } \\
\text { feeling. [...] It's just so cloudy, fluffy, like skin sensations. Something } \\
\text { spongy like that. It is also a bit dizzy. It is still difficult to make sense of it, } \\
\text { because it is always very different. [...] Yes, but in a very pleasant way. Not } \\
\text { bad at all. It is something cheerful. Like when you sit in the sun and drink } \\
\text { two beers." }\end{array}$ \\
\hline $\begin{array}{l}\text { L3 } \\
\text { EPISTEMOLOGICAL }\end{array}$ & $\begin{array}{l}\text { Religious experiences in worship can also be epistemological, meaning } \\
\text { that the worshipper experiences the unfolding of some new divine } \\
\text { understanding or knowledge. }\end{array}$ & $\begin{array}{l}\text { "A certain thought came to my mind about who God is. It happens either } \\
\text { through a song or a song text, where I suddenly understand something in my } \\
\text { heart that I had only heard before. And by listening, realizing and feeling } \\
\text { the atmosphere of a song, it grows into my consciousness - or into my heart. } \\
\text { Two such experiences come to mind, where I was quite touched the moment } \\
\text { when I realized it. The same can also happen when God speaks to me in my } \\
\text { times of worship." }\end{array}$ \\
\hline $\begin{array}{lll}\text { L4 } & & \\
\text { THE } & \text { RALITY OF } \\
\text { GOD } & \end{array}$ & $\begin{array}{l}\text { One of these epistemic instances is that one gradually or suddenly thinks } \\
\text { to understand more about the reality and nature of God. This is not } \\
\text { surprising because often, worshippers feel to be experiencing a } \\
\text { connectedness with God and it is only normal that one then also thinks to } \\
\text { understand more about him. }\end{array}$ & $\begin{array}{l}\text { "Sometimes it happens in a moment where I suddenly understand who God } \\
\text { is and who I am. And the I feel incredibly loved and I am amazed at his } \\
\text { greatness."; "I think then I just realized who God was." }\end{array}$ \\
\hline $\begin{array}{l}\text { L4 } \\
\text { CLARITY }\end{array}$ & $\begin{array}{l}\text { There is one particular experience where a person gets a sudden lift of } \\
\text { fogginess where it seems that one has been in the dark until now, but the } \\
\text { veil has been lifted. There is an unusual perception of clarity involved } \\
\text { therein. }\end{array}$ & $\begin{array}{l}\text { "But God spoke to me and there was so much power in what he said that I } \\
\text { could only cry. It was so crystal clear that it was HIM. Sometimes I hear } \\
\text { something where it is less clear if the talk comes from God. But in these } \\
\text { special moments you simply know: this was him!" }\end{array}$ \\
\hline $\begin{array}{l}\text { L4 } \\
\text { KNOWLEDGE }\end{array}$ & $\begin{array}{l}\text { One can have gradual or sudden knowledge about God or the world as a } \\
\text { consequence of getting in contact with the divine. }\end{array}$ & $\begin{array}{l}\text { "I have the feeling that it is that moment where the intellect and the heart } \\
\text { are in the same place. It is not exclusively one. It is as if one can think } \\
\text { absolutely clearly. The heart does not decide what your head thinks and the } \\
\text { head does not decide what your heart does. Before God, suddenly everything } \\
\text { is revealed. You know how He looks at you and you can control that: hey, } \\
\text { is that true? You can tell other people what you have heard from God and it } \\
\text { is like hitting the nail on the head." }\end{array}$ \\
\hline
\end{tabular}




\begin{tabular}{|c|c|c|}
\hline $\begin{array}{l}\text { L4 } \\
\text { UNDERSTANDING }\end{array}$ & $\begin{array}{l}\text { Sometimes, it goes even deeper than the belief that one receives divine } \\
\text { knowledge: one can even sense to be suddenly understanding deeper } \\
\text { truths that can be integrated in one's life. }\end{array}$ & $\begin{array}{l}\text { "An intense experience was when God revealed certain things to me: once, } \\
\text { it had to do with the future. God told me: 'You will distance yourself from } \\
\text { me again for this-and this reason.' And it was pretty shocking to me to hear } \\
\text { that. I think these were revelations or insights, which then each time had } \\
\text { shocked me quite a bit. Another one was to realize what his love really } \\
\text { means to me. And that it is much greater. I can't do anything about it because } \\
\text { his love doesn't even depend on me. And I found that very moving. The song } \\
\text { Reckless Love was also formative here. The song was developed exactly for } \\
\text { that reason..."; "A certain thought came to my mind about who God is. It } \\
\text { happens either through a song or a song text, where I suddenly understand } \\
\text { something in my heart that I had only heard before. And by listening, } \\
\text { realizing and feeling the atmosphere of a song, it grows into my } \\
\text { consciousness - or into my heart. Two such experiences come to mind, } \\
\text { where I was quite touched the moment when I realized it. The same can also } \\
\text { happen when God speaks to me in my times of worship." }\end{array}$ \\
\hline $\begin{array}{l}\text { L4 } \\
\text { HEARING } \\
\text { SPEAK }\end{array}$ & $\begin{array}{l}\text { Already mentioned before, one can be hearing the voice of God, either } \\
\text { internally (with the mind) or externally (with the ears). Hearing his voice } \\
\text { often comes along with gaining some new insights. }\end{array}$ & $\begin{array}{l}\text { "I believe that it is really like a thought when he speaks to me. Like a } \\
\text { realization you suddenly have and that has not made sense before. This is } \\
\text { the last piece of the puzzle and suddenly you see the picture. It's like a } \\
\text { realization that gives you a completely different perspective." }\end{array}$ \\
\hline $\begin{array}{l}\text { L2 } \\
\text { INDUCTION }\end{array}$ & $\begin{array}{l}\text { Religious experience in worship can be induced by the worshipper, the } \\
\text { worship band, or by other means. This can occur either intentionally or } \\
\text { unintentionally. }\end{array}$ & $\begin{array}{l}\text { "Yes, music can be a gateway. It can help. But I could experience God in } \\
\text { exactly the same way, whether it has music or not. But it helps to focus on } \\
\text { him, to let creativity flow, to worship him through creativity. This is very } \\
\text { biblical: look at the psalms. It helps me personally." }\end{array}$ \\
\hline $\begin{array}{l}\text { L3 } \\
\text { INTENTIONAL }\end{array}$ & $\begin{array}{l}\text { If a believer is not new to the field, it appears to be possible to introduce } \\
\text { such a divine experience at will. }\end{array}$ & $\begin{array}{l}\text { "No, worship does not specifically help me to sense the presence of God, } \\
\text { but it helps me to focus on God."; "Yes, with songs I can steer such } \\
\text { experiences. There are songs that can pick me up in the situation where I am } \\
\text { now. This can influence me strongly." }\end{array}$ \\
\hline $\begin{array}{l}\text { L4 } \\
\text { ACTIVE }\end{array}$ & $\begin{array}{l}\text { When respondents are asked about how they can initiate a religious } \\
\text { experience, it is often described that it has to do with an active focus on } \\
\text { God. The music helps people to focus on God in worship and the better } \\
\text { this is achieved, the more believers report to have experiences which they } \\
\text { would label as divine. This is not a passive process but often requires } \\
\text { active decision making. Usually, one must deliberately decide to focus on } \\
\text { God and to enter the atmosphere. }\end{array}$ & $\begin{array}{l}\text { "Music in worship helps me a lot to focus on God and praising him or to } \\
\text { proclaim biblical truths where I feel that they need to be stated clearly again: } \\
\text { e.g. shouting the name of God as a statement into the world. I wouldn't even } \\
\text { dream of doing something like that without music, if I can choose. It helps } \\
\text { me a lot. It is almost like I can get on a boat that takes me along on a river } \\
\text { with what I do."; "On the other hand it is also a conscious decision: do I } \\
\text { want to put down my little circle now, around which I am currently turning } \\
\text { myself? Or will I invite God to deal with these things, or do I want to do it } \\
\text { myself. I think, getting into this state of mind where I can get close to God } \\
\text { in worship is my part. I have to decide upon it. "; "Yes, if there is something } \\
\text { I can control myself, it is surely the conscious decision of focusing on God. } \\
\text { I can say to myself: "now is my time with Jesus, with the Father and with }\end{array}$ \\
\hline
\end{tabular}


L4

\section{ATTITUDE}

L4

SPIRITUAL

TRACKS

TOP-

TRACKS

\section{ENVIRONMENT}

EFFECT

\section{L4 \\ REGULARITY}

EFFECT

\begin{tabular}{l|l} 
& \\
& \\
& \\
\hline L3 & \\
UNINTENTIONAL & \\
\hline L4 & \\
DISTRACTION & (RUMINATION \\
EFFECT) & \\
\hline L4 \\
BOREDOM EFFECT
\end{tabular}

Focusing on God is one thing but having the right mental predisposition is another. The second can be described as "one must be in the right mood" or "there has to be the right attitude" to worship and to engage with the experience.

There are also some songs where there is a history present with the practitioner. These tracks are very helpful for the induction of divine experiences because they have proven to transport a certain facilitating atmosphere to the worshipper. If they are employed, a religious experience may not be guaranteed but may become relatively likely.

The environment effect states that the setting can be of key importance for the induction of such an experience. The environment can be that one is alone or in community, that one is outside or in a house, that one is surrounded with stage and disco lights or in the dark. All these things can influence the mood and a person's capacity to concentrate on God, which eventually can lead to a divine experience.

The more one uses a song that one likes, the easier it becomes to induce a certain phenomenal state. The reason for this is simple: if the process has been walked through time and time again, it does not require a lot of cognitive work to get oneself into that specific mood. However, it can also go the other way around. If the regularity effect is overdone, meaning that one uses a song too much, then the tables can turn and it becomes extremely cumbersome to be open for the experience. Hence, up to a certain degree, the regularity effect can be facilitating the experience but if one exceeds this point, it can become hindering.

One can intentionally strive to enter a divine experience but it can also occur unintentionally. There are hence unconscious factors at play.

Perhaps one of the most intuitive factors is when one is distracted. Then, the person begins to ruminate and has difficulty to focus on something specific. This is what I refer to as the rumination effect.

Similar to the extreme form of the regularity effect, one can become bored of a given song. The participant then loses his or her attention span and the Spirit. Now I put down my cell phone and have nothing disturbing left.' Then sometimes I have to endure the silence a little bit. Or I sit down at the piano. But there is never a guarantee for a special experience. Sometimes I experience something and sometimes I don't."

"I think it has to do with my own attitude. How strongly am I willing to dive into the worship or how strongly am I still preoccupied with myself?"

"For sure - there are a lot of songs where I know: if I listen to them, I have this platform of feeling close to God and enter the worship setting. I find this platform is when I can dive in with the song and seek God. How strongly I feel God after that I can't say, it's not always the same. But I have these songs, if I engage with them, then this invitation or this platform is there to get closer to God. Let's put it this way: when I listen to these songs, I am per se one step closer to God, because this space is created where there is a separation between the outside and the inside."

"It helps me a lot when I'm not distracted by people. That is, when it's dark and I know that nobody can observe me right now. I think such factors help me a lot. If the worship appeals to me, if I realize that this music is close to my heart; that's where I find myself and God. And also when the other people are not distracted or hungry for an encounter with God."

"It has to do with the fact that I do this regularly. Being distracted doesn't happen so often ever since I attend the soaking group regularly and ever since I've started to have time with God on a regular basis. Then it happens more easily. As I said, when you see a friend only once a year, it takes more time to get warm with each other. And when you see each other a lot, then it doesn't take as long. [...] Yes, it is an investment. Every relationship is an investment that you have to do."

"It is like a rail: there is a part I can contribute to, but in the end it still depends on God, how, what and where he wants to meet me."

"I actually felt bad for many years and thought that there was something wrong with me. Because when I am alone, I do not have such strong experiences with God. It's very difficult for me to sit down alone and worship."

"It has to do with the music style that can distract me when it is too simple. When it is too repetitive, the it starts to bore me."; " 


\section{L4 \\ FAMILIARITY}

EFFECT

(1)

L4

MEMORY EFFECT

L4 MUSICAL QUALITY
EFFECT

L4

\section{MODEL \\ AUTHENTICITY}

EFFECT

L4

SPONTANEOUS

\begin{tabular}{l|l} 
& th \\
& \\
\hline L4 & A \\
SPECIAL & a \\
ANOINTING & in \\
\hline
\end{tabular}

The best-case-scenario is that a song effects a mental back-flash, meaning that the song remembers the person of a divine experience in the past that has occurred with exactly this song. When this happens, the person often gets automatically drenched in the same attitude and mood again which can in turn facilitate a new divine experience of the same sort.

As seen before, the musical quality can be good or bad (please note that this is a matter of subjective taste). If the believer does not resonate well with the tune and does not think that the quality is good, then it can serve as a tremendous distraction. The opposite is true if the music is good and liked by the participant. Then it can help to induce such an experience.

When worshipping in a congregation, one is not alone. In this setting,

AND there is usually a person, a team or a band leading the worhip ceren These leaders can be role models on the stage and if people in the congregation get inspired by them, they can help in the induction of a divine experience.

One element which the interview participants have highlighted is that there is an inevitable spontaneity involved. To some degree, it is perceived as "not in my hands" whether one can have an experience with God during the worship ceremony or not.

A rather cryptic idea is that sometimes there is a what some believers cal a special anointing in the room. This means that the atmosphere is set out in a way as that it becomes incredibly easy to connect with God. This is
"It helps me a lot when I already know the songs well."; "I can say: yes, there are those songs where it is very easy for me. And that is - this is an exciting question, because I have already observed it myself: they are not the best songs, not at all. Rather, they are always songs that I had heard over and over again in a certain time span, in which I experienced God in a very special way. And when I take them out again - there is an album that I've been hearing for 15 years. The music is terrible. But I can get in there and bam - there it just comes. Because a certain conditioning is there."

"I think in the first place it is the sound. For example, if I have songs that touch me deeply, then I can hear the first chord and I am almost back in this divine experience. And there hasn't even been anything sung yet. Well, I know what the song is about because I know the song. That's the point. But the chord alone is enough to get me into this mode or atmosphere."; "When I hear an instrumental and it triggers emotions where I have experienced something similar to what I am now longing for, I immediately feel transported back to that atmosphere."

"In order to dive into the worship, it is has to do with how the instruments are played. One the one hand the musical quality and on the other hand, the attitude of the instrumentalists."; "It helps me a lot when the musical quality is good"; "But with the music of bad quality: it triggers so many negative emotions. It evokes feeling bad for others: what do the people think? It is almost like a cramp because it hurts. This makes it incredibly difficult."

"It helps me a lot when there is a role model - when other people in the same room are also worshipping and seeking God. I don't need it but it helps. It is very helpful when it's authentic. With this I mean that you can see that the people who set an example are really worshipping from the heart. This helps a lot."

"This is special when the anointing comes [where there is a level of spontaneity]. I have to say this: when the Holy Spirit comes and enables me to stand on the stage, it acts like an amplifier that makes the whole show much stronger. I also feel much freer, which is even more exciting. [...] It is just this element, that this is not just me who decides to worship, whether I am doing well or not - but it is the Holy Spirit who comes with his power because I am doing him a service. He comes when he wants."

"I believe that music styles can help us to pick up. But it's not really dependent on that. It can be that a whole band is there and everything plays perfectly. And still there is no breaking through into the presence. And 
L4

MUSICAL

\section{MUSICAL}

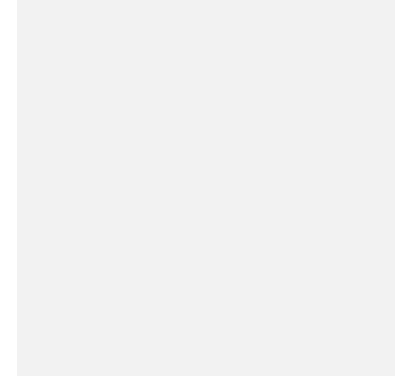

L4

BODILY

ENGAGEMENT

L3

L4

MOTIVATIONAL

'SEASONS' not believed to be a natural thing but a divine and spiritual element in the room which humans cannot generate by themselves. This one is linked to the 'spontaneous' category.

To all the worshippers in the sample, the musical embedment helps a lot.

Music can transport an atmosphere like no other form of art and hence is

a tool regularly used to help focusing on God and to get to such an experience.

Whereas some people like to stand, sit or lay still, others require physica engagement. To them, when they have movement, they feel activated and this helps them to get in the right mood.

another time there might be just one person with the piano on stage and it is just insane from the first moment. It just can't be that the style is responsible for God's working. It is simply God who gives it when he wants to and who then provides a special anointing."

"Music is a lot more to me than simply a tool. It is an expression of God's creativity through us humans."; "I think to a certain degree we can influence ourselves whether we get close to God or not. Always provided that music playing is of the sort that I like. For example, if the worship is very jazzy. Then I don't feel in the mood or emotional state where I find myself in this intimacy. This is not a state which enables me to meet God. If it is very jazzy, then I am more likely to listen and I am more passive. Provided that the music is such that I feel comfortable and it doesn't push me into the listening position, then for me it is like a virtual space that separates me from the outer world, what there is, and allows me to meet God in that space. The music helps that less of the outside distractions reach me. Then I'm a little isolated and I can come into a flow with the focus on God - with the will to seek God - where I feel that I have some time with God now."

"But sometimes I get very excited, so that I have to stand up and express myself with my body in worship. But I also have the quiet moments."; "“"No [laughs]. Music does not help me to feel God. But it helps me to feel holistic - I find music to be something incredibly holistic. That means there is a beat. The body moves. And then you sing along and the mood is activated. And through the holistic activation the thoughts are activated in the head, which you then also express. This means that the music helps me to set my mind holistically on God. This is how it helps me."

"That depends extremely on the form of the day and what is going on around me. The song does not dictate the whole experience for me. If I have selected the songs myself, then the chance that I can dive into the worship is of course easier for me. Because normally I have a higher connection to it them."; The hybrid cluster is mainly defined by the categories below.

It can vary or be something in between. These special cases are labelled 'hybrid induction' in the present model.

This has a lot to do with one's mindset predisposition. It depends on the situation, the time and the motivational circumstances whether an induction works or not. Such a 'season' can be a specific time of the day or a time span over several months, for example. It is a season where one is especially open for such experiences.
"The lyrics are more important for me than the style. The style that helps me the most is not the same every day. Sometimes you have days where you need calm songs to lead you into worship and sometimes you have days where you need a motivational and high-beat song."; "It certainly has to do with what God is doing in my life right now or how he wants to come. There were times when I was so down and frustrated. I had experienced a lot of depth and I practically always experienced God in this time. He wants to meet you where you need him the most. I have often experienced that, it's a 


\begin{tabular}{|c|c|c|}
\hline & & $\begin{array}{l}\text { real phenomenon: when you feel bad, you seek God more and when you } \\
\text { seek Him more, you experience Him more." }\end{array}$ \\
\hline $\begin{array}{l}\text { L4 } \\
\text { CULTURAL } \\
\text { CORRESPONDENCE } \\
\text { EFFECT }\end{array}$ & $\begin{array}{l}\text { If the music is far away from the cultural habits of a person, it is more } \\
\text { complicated to concentrate on what the worship ceremony is about. } \\
\text { However, if the music corresponds well to the person's cultural tastes, the } \\
\text { opposite is the case. }\end{array}$ & $\begin{array}{l}\text { "That's funny: it's a cultural thing. It was the same } 10,20,30 \text { years ago: one } \\
\text { song was more rock-style, driven by the guitar. Now it's very spherical, } \\
\text { heavy with pads and all that. I think it's cool, because in this style of music } \\
\text { you give people a lot more space. There is less going on music wise and that } \\
\text { opens the door for the platform that you can worship God in this setting with } \\
\text { your own words. There you can sing your own melody over a pre- } \\
\text { established melody. This works better than when a song is fully arranged or } \\
\text { when the chord changes every two seconds. Then it becomes harder to find } \\
\text { an approach." }\end{array}$ \\
\hline $\begin{array}{l}\text { L3 } \\
\text { REACTION } \\
\text { FAILURE }\end{array}$ & $\begin{array}{l}\text { When believers set out to worship God, they often do so in the hopes of } \\
\text { getting a divine experience in return. However, this induction not always } \\
\text { works and there are several ways how one can respond to it. }\end{array}$ & $\begin{array}{l}\text { "There can also be worship times where I walk off the stage at the end and } \\
\text { think: gosh, I fought hard and was completely alone; I didn't feel the power } \\
\text { of the Holy Spirit at all. Uhm, sometimes I am challenged with this in } \\
\text { thinking that I have failed or that it was not enough [what I brought]. Over } \\
\text { the years I have learned that my feelings on stage give no indication at all } \\
\text { of what God has effectively done. I don't think there is even a real } \\
\text { impression of what He was doing in me. I believe that I am much more } \\
\text { complex than I can consciously reflect and perceive myself. I believe that } \\
\text { God meets me even when I do not feel him. Well, no, from that point of } \\
\text { view: I do not always feel God in worship." }\end{array}$ \\
\hline $\begin{array}{l}\text { L4 } \\
\text { FRUSTRATED }\end{array}$ & $\begin{array}{l}\text { One option is to become frustrated and leave it at that. Then the whole } \\
\text { worship experience will not be a pleasant one. }\end{array}$ & $\begin{array}{l}\text { "Of course, there are moments where I do not experience God and where I } \\
\text { would have wished for it strongly. Then there is a hunger or a dissatisfaction } \\
\text { present."; "There were times where I did not feel God at all in worship and } \\
\text { this was extremely difficult for me. But after a while, it comes back." }\end{array}$ \\
\hline $\begin{array}{l}\text { L4 } \\
\text { SEEKING } \\
\text { ANSWERS } \\
\text { SOLUTIONS }\end{array}$ & $\begin{array}{l}\text { The perhaps most common response is to become a little frustrated and } \\
\text { then to try to find out why this is happening. The worshipper seeks for } \\
\text { answers and intends to solve this problem. The goal would be to get back } \\
\text { on track and to induce a divine experience. }\end{array}$ & $\begin{array}{l}\text { "I sometimes ask myself: crap, did I get too involved and therefore I felt } \\
\text { nothing, or did I let myself get distracted too much by things that bother me? } \\
\text { That's what I try to find out in each case, because I generally try to be open } \\
\text { and not prejudiced. But sometimes I also think: no, I was actually very open. } \\
\text { So, it's ok to not experience God at times. I can only influence it to a limited } \\
\text { extent. I can influence it with my willingness to listen and to be open. But } \\
\text { in the end, I have no control over whether such an encounter really } \\
\text { happens." }\end{array}$ \\
\hline $\begin{array}{l}\text { L4 } \\
\text { NONCHALANT }\end{array}$ & $\begin{array}{l}\text { The last option is to find peace with the situation that a tremendously } \\
\text { spiritual experience is not always going to happen. These people react in } \\
\text { a nonchalant fashion and do not take too much issue with it. }\end{array}$ & $\begin{array}{l}\text { "It doesn't bother me when 'nothing special happens' during the worship } \\
\text { event. And when I don't like the song, there is in principle nothing that keeps } \\
\text { me from still talking to God or to try to listen to him." }\end{array}$ \\
\hline
\end{tabular}

